Article

\title{
BIM and Sustainability Education: Incorporating Instructional Needs into Curriculum Planning in CEM Programs Accredited by ACCE
}

\author{
Jingxiao Zhang ${ }^{1,2, *}$, Klaus Schmidt ${ }^{3}$ and Hui $\mathrm{Li}^{1, *}$ \\ 1 School of Civil Engineering, Chang'an University, No. 161, Chang'an Road, Xi'an 710061, China \\ 2 College of Engineering and Technology, Xi'an Fanyi University, No. 161, Taiyigong Road, Chang'an District, \\ Xi'an 710105, China \\ 3 Technology Department, Illinois State University, Normal, IL 61790, USA; kschmid@ilstu.edu \\ * Correspondence: zhangjingxiao@chd.edu.cn (J.Z.); lihui9922@chd.edu.cn (H.L.)
}

Academic Editor: Marc A. Rosen

Received: 6 February 2016; Accepted: 9 May 2016; Published: 31 May 2016

\begin{abstract}
Higher education ought to support the identification of training needs for industrial building information modelling (BIM) curriculum development and sustainability education in the fields of civil engineering and management (CEM). This paper proposes a framework based on a four-phase step-by-step quality function deployment (QFD) application for CEM curriculum planning and quality management. The framework attempts to respond to requests collected from 17 professionals and professors in order to integrate BIM into the higher education curriculum in China with a specific focus on construction management programs accredited by the American Council for Construction Education (ACCE). The entropy method and a K1-K6 scale adapted from Bloom's revised cognitive process were employed to evaluate the CEM curriculum in QFD. The proposed framework was successfully applied to CEM curriculum planning, which included two curriculums of the four main knowledge areas provided by the Chinese CEM guidelines: construction cost and flow construction. Two curriculum areas showed that content should focus on knowledge such as (a) Program evaluation and review technique(PERT) planning; (b) construction optimization in flow construction; (c) principles of bill of quantities and (d) construction consumption in construction costs. As for teaching quality management in China, the higher education curriculum should focus on three aspects to promote curriculum integration: (a) pedagogical design; (b) teaching resource and material and (c) curriculum assessment. This research sheds light on the pedagogical shift to a similar context that has established guidelines accredited by the ACCE, with respect to reviewing curriculum planning from a knowledge system perspective in order to meet industrial demands at the operational level.
\end{abstract}

Keywords: education for sustainability; building information modelling (BIM); BIM capability; civil engineering and management (CEM); quality function deployment (QFD); curriculum planning; entropy method

\section{Introduction}

Architectural, engineering, and construction (AEC) industries use indicator terms such as life cycle costing, ecological footprint and carbon footprint to implement sustainable green-building design approaches [1,2] in an effort to improve the energy efficiency of construction projects. Building information modelling (BIM) is increasingly being applied throughout a building's lifecycle, including in building renovation, energy simulation, and building system analysis throughout all processes of AEC and facility management (FM) domains. The United Kingdom, for example, is making BIM 
mandatory on all public projects from 2016 in order to cut waste and monitor sustainability [3] (p. 80). The innovation of BIM technology provides a new means of predicting, managing and monitoring the environmental impacts of a project's construction and development phases through a "one-stop-shop". BIM is helpful for environmental sustainability monitoring and management over a building's full life cycle. Furthermore, BIM presents the opportunity by the information embedded in a building project to expand its scope within sustainability [4]. BIM would also be most beneficial at the conceptual design stage so that sustainability is built into the design solution starting from its inception. BIM allows for sustainability to become a key component of the design, construction and delivery of a building and enables the corresponding decisions that affect its environmental performance, to avoid costly redesign or engineering waste [5] (p. 268).

It could be argued that without BIM talent development, no real progress toward AEC sustainability could be made. Civil engineering and management (CEM) in higher education curriculum planning provides a sound foundation to train BIM talent to meet the AEC industrial needs. Throughout this process, it may be further argued that it is imperative to intelligently convert AEC industrial BIM needs into the corresponding curriculum development. Thus, at present, the rising concern about the lack of BIM education in higher education has been a focus of research around the world as the demand for talent will promote the AEC industrial sustainability [6]. These challenges may be addressed by modifying curriculum content and setting new priorities for CEM in higher education.

Research showed that CEM education has traditionally been delivered based on specific CEM undergraduate student guidelines $[7,8]$, in which BIM-driven knowledge domains are logically infused and supported by the required knowledge areas which are derived from a variety of quality management related curricula. Numerous studies also reviewed the current status of BIM training and its respective elements to meet the needs of industry and align with the expectations of new and challenging job demands [7,9-14].Those elements include single BIM curriculum integration, BIM curriculum guidelines, and BIM teaching methods. Therefore, BIM-driven knowledge domains may require a pedagogical shift by way of integrating training of industrial BIM capabilities with related business and management curricula, and include supportive insights from both university faculty and industrial professionals. This is to say, addressing BIM industrial needs in academic curriculum development is therefore imperative in all related curriculum planning efforts. Only then can CEM graduates quickly overcome the gap between industrial sustainable requirements and traditional university curricula and swiftly adapt to the AEC workplace $[15,16]$.

In the meantime, quality deployment function (QFD) may provide a foundation from both educational and industrial perspectives and from a knowledge system view point [17-22], and QFD is applied in engineering education in order to translate key requirements for the field into an effective curriculum and to enhance instructional quality [17,23-25]. The same research may have identified a lack of integration between BIM and other supportive curriculum areas [8]. For example, Kamvysi et al. [13] proposed and tested the use of an alternative framework for prioritizing students' requirements within QFD; Liu et al. [20] proposed an industrial design curriculum that meets practical workplace needs by applying QFD.

The purpose of this research is to systematically identify priorities for successful curriculum development in CEM using QFD as a guideline, and to respond to the increased need for talent development in the area of BIM in China. There are four main knowledge areas in the Chinese CEM guidelines: (a) management; (b) contract and law; (c) civil technology and (d) information technology and management. These knowledge areas cover the comprehensive curriculum such as construction cost, flow construction management, engineering graphics, building technology, construction law, and civil engineering [26].

This research could stimulate a pedagogical shift in China and other countries that have guidelines accredited by the American Council for Construction Education (ACCE), towards giving more attention to BIM related curriculum planning and thus moving away from the current CEM approach in order to better meet BIM talent training demands. The research further identifies a more flexible and advanced 
development of BIM related curriculum in CEM which is prepared specifically by both faculty and industrial professionals using newer didactic criteria and case application [27-29].

The remainder of the paper is structured as follows: Section 2 includes a brief review of related literature such as QFD applications in curriculum development and the need to enhance industrial BIM capability. Section 3 provides the methodology. Section 4 implements the procedure and measurement to analyze two of the six existing curriculum areas in CEM. Section 5 presents the conclusions and summarizes the results to highlight the similar curriculum development attempts in CEM.

\section{Theoretical Background}

\subsection{Sustainablity Education and BIM}

In order to address challenges faced by continuously moving toward sustainability in China, higher education in China should be regarded as a marketable service with qualified, knowledgeable graduates who will contribute positively to society [30]. For students, higher education is a means to employment. In the construction world, engineers must be flexible and able to respond to sudden changes weather these changes are introduced through international and local government demands, sustainability policies, or construction needs. Engineers of the future must be able to function in a team environment, often globally, and be able to relate their technical expertise to societal needs. Higher education has to focus on market demand and stop defending obsolete programs. In order to prepare engineers to meet these new challenges, engineering training and education in China must be revised and modernized. The researchers of this paper will look at the contributions that can be made to CEM education, and will place emphasis on establishing teaching at the university level with an attempt to integrate the industrial capability needs to improve the overall quality of curriculum and education in construction [9].

Construction is rapidly moving towards sustainability. Due to the demands of the environment, more sustainable buildings will need to be constructed. These buildings will use materials that could decrease negative environmental impacts during the lifecycle of the building. For example, the UK government's Construction 2025 strategy targets a 33\% reduction in the whole-life cost of built assets and a $50 \%$ reduction in greenhouse gas emissions by 2025 [3]. The construction industry will benefit from an integrated tool that helps optimize the selection process of material, equipment and system at every stage of a proposed building's life-cycle.

$\mathrm{BIM}$ is one of the most promising recent developments in the AEC industries. BIM represents a new paradigm within AEC and helps architects, engineers, and constructors visualize and simulate to the project to identify any potential design, construction, or operational issues and helps furthermore to integrate sustainability regulations and assessment measures [4,31,32]. For example, BIM technology provides an accurate automated sustainability compliance checking virtual modelling tool of a proposed building. BIM is intrinsic to sustainable design and assists with the design and measurement of a building's environmental performance. However, perhaps its most important contribution to sustainability is the elimination of waste throughout a building's life-cycle. In the case of Britain, BIM is a vital mechanism to achieve the goal of lowering carbon production by $80 \%$ by 2050 (compared with 1990 levels) [3].

As shown in Figure 1, the overlapping aspects of sustainability education and AEC industrial sustainability needs requires institutes of higher education accredited by the ACCE to understand how to best utilize BIM to meet the increased demand on sustainability in AEC industries. At the same time, in a globalized world, the basis of engineering education is made up of unique experiences, traditions and everlasting values of specialist training at universities. Therefore, CEM education should adopt new and innovative industrial skills (such as BIM) into curriculum design along with opportunities and the flexibility to include important trends and advances in sustainable development, such as cutting construction waste or carbon emissions. Thus, CEM programs should consider introducing industrial BIM concepts and tools that enable students to apply relevant skills, and make them aware 
of potential BIM applications to prepare them for their future careers. These curricula advances would then in turn also improve industrial sustainability overall.

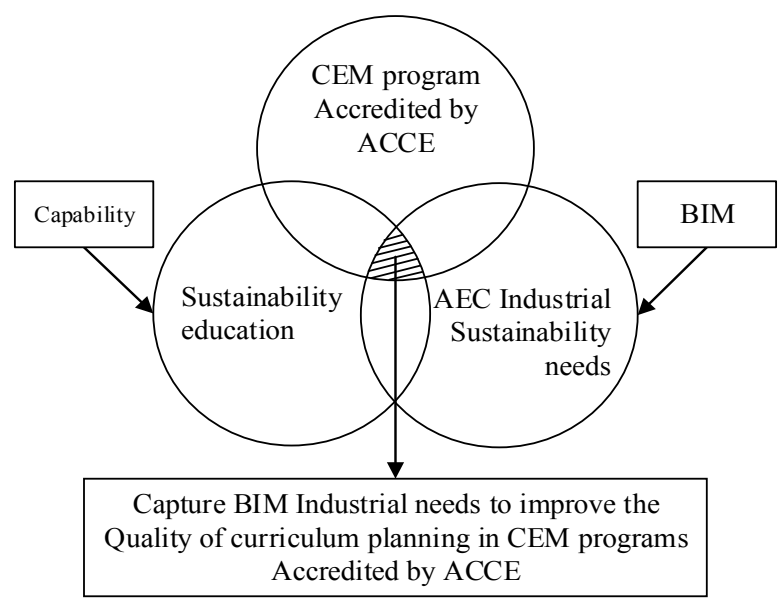

Figure 1. Overlapping of key concepts regarding building information modelling (BIM) in relation to its integration into curriculum planning of civil engineering and management (CEM) programs accredited by the American Council for Construction Education(ACCE) in order to adapt to the needs of architectural, engineering, and construction (AEC) industries.

Higher education should therefore integrate industrial BIM concepts and technologies into CEM supporting curricula, and then help to meet industrial sustainable development in those respective industries. This integration will equip CEM students with relevant preparation for industrial demands. Only if students utilize BIM effectively will sustainable construction succeed in the future.

\subsection{Industrial BIM Capacity}

Implementing BIM concepts and tools into the construction industry heavily relies on the knowledge that new construction employees bring into the labor market. Only then can BIM continue to gain momentum and successfully change the industry. A thorough understanding of the opportunities that BIM applications provide constitutes essential drivers for its adoption throughout the entire construction process [31]. Industrial demand for BIM education around the world continues to increase. AEC industrial benefits of BIM have included: (a) fully integrated projects; (b) buildings that are fully designed before construction commences; (c) fully coordinated cost models and building programs; (d) increased likelihood of the finished building conforming to the agreed design; and (e) significant cost reductions due to improved effectiveness and productivity $[33,34]$. Thus, there is a need for integrating BIM knowledge and skills into the curriculum. Higher education therefore plays an important role to provide the necessary conditions for the implementation of BIM in the construction industry. However, market demand for graduates with a workable BIM skill set has not been able to keep pace with this apparent and rising demand for BIM capability in industry [31]. Therefore, BIM capacity building has become one of the key skills of AEC practitioners (architects, engineers, contractors), manufacturers, and other professionals [35]. The synergistic modeling characteristics of BIM make it an effective tool for all practitioners in the construction industry. However, one deficiency of BIM technology is its slow adaptation to the demands of AEC industries. For example, newer and more modern professional BIM software tools should be developed to address the needs of different building types. Barlish and Traylor highlighted that:

the students should not be considered as stakeholder by reasoning that students use the curriculum but often lack information regarding the competencies needed in their vocations and are unable to assess the curriculum from a customer's point of view. However, the school faculty should have the competency to evaluate the vocational and technical courses to be taken by the students. [36] 
Based on BIM related literature, industry-academic partnerships [10,12,37-39], BIM education guidelines [7,8] and the 2015 National BIM Standards for the United States [37] provide a basic structure to align BIM education with industrial demands. Figure 2 is an overview of BIM industrial capability based on the above studies.

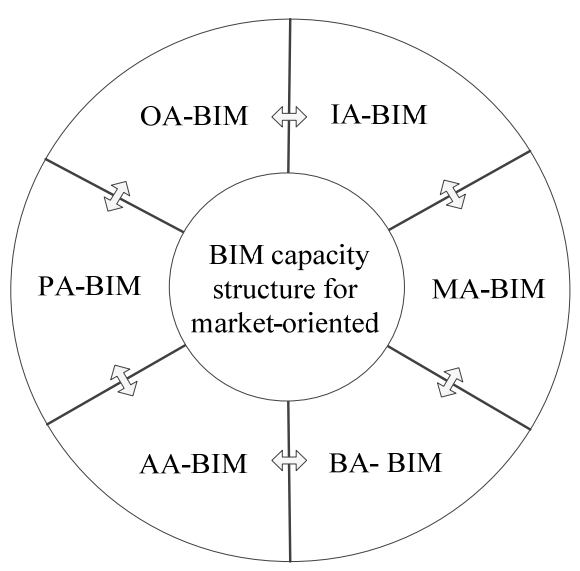

Figure 2. Building information modelling (BIM) capacity structure for curriculum development, pertaining to the operation ability of BIM software (OA-BIM); the production ability of BIM models (PA-BIM); the application ability of BIM models (AA-BIM); the building ability of BIM application environments (BA-BIM); the management ability of BIM projects (MA-BIM); and the integration ability of BIM businesses (IA-BIM).

The operation ability of BIM software (OA-BIM) requires that BIM professionals must have abilities to operate one or several BIM software applications. This ability should be the essential and basic ability of engineers for BIM model production, BIM information application, and BIM professional analysis. The production ability of BIM models (PA-BIM) refers to the ability to build models for different types of buildings using BIM software. The different types of models include construction models, structural models, site models, electromechanical models, performance analysis models, and safety precaution models. The application ability of BIM models (AA-BIM) signifies the ability to analyze, simulate, and optimize tasks during different phases of a project, including project demonstration, performance analysis, design inspection, and operation process simulation. The building ability of BIM application environments (BA-BIM) pertains to the ability to build a technical environment for a BIM application that consists of the organization and delivery of standard, workflow, component assembly inventory, software, hardware, and network. The management ability of BIM projects (MA-BIM) is the ability to manage and coordinate BIM project teams to achieve the goal of BIM applications, including the establishment and training of project teams. The integration ability of BIM businesses (IA-BIM) designates the ability to integrate BIM applications and the business targets of enterprises include the confirmation of the value of BIM to enterprise businesses, the calculation and estimation of the BIM investment return, the establishment of new business models.

\subsection{BIM Education in CEM}

BIM enables architects, cost estimators, engineers, builders, and property owners to manage a project in its entirety in a timely manner. BIM can improve the communication between enterprises across the entire construction industry. BIM can enable information management and help throughout the lifecycle of a project. With the constant progress of building design, bidding, construction and operation, BIM will continuously show its value in the management of the lifecycle of buildings.

BIM curriculum in CEM embodies the process from simple modeling, to the junior-intermediate applications of senior skills. CEM graduates can adapt to BIM requirements and gradually gain the business integration capacity after project practices. For BIM education in undergraduate CEM, there are various phrases and methods that could be used for the course development. 
For example, the civil engineering body of knowledge (CEBOK) states that the knowledge and skills of BIM-supported communication, cooperation, problem identification, and solution become very critical to civil engineers [40]. CEM reinforces that enhancing BIM education by building systematic and comprehensive BIM education methods has become the focus of the reform of college course [13,14]. In the undergraduate programs of CEM, BIM courses should focus on the cooperation and management at cross-organization and cross-project level [41-43]. For example, Forsythe [40] provided an approach to adopt the term "vertical problems" to capture the way models and problem based learning are being utilized, where staff author "sub-plots" that utilize information models in a way that best suits their specific subjects, e.g., cost, time, quality, sustainability subject areas.

For CEM education in the USA, although colleges have added BIM contents to the existing courses and delivered them in various approaches and methods, it does not mean that BIM teaching is generally implemented with high quality [44]. Many colleges provide BIM education only in 1-3 separated courses. This setting reduces the knowledge coverage of BIM to an introduction level with the retaining duration of only 1-2 weeks [14,34]. To improve the application level of BIM in CEM, educators should incorporate BIM instructions in an independent course in the primary stage of CEM education. For example, in China, BIM education is introduced earlier in an educational course than in the USA [45].Chinese researchers used the independent BIM platform to integrate sustainable building design [46], and adopted the BIM workshop to implement the large-scale design competition [47]. Moreover, BIM contents can gradually penetrate through other courses. The design and development of courses that integrate BIM should depend on the analysis of course development theory, current demands, trends of construction engineering education, and the production process of construction management [48]. To identify the multilateral relationships among BIM contents and the possible CEM courses to integrate and to organize the contents in a consistent and coordinate manner, this research can be applied to the QFD house method for the implementation.

BIM education for CEM students meets the demands of industries and helps to improve the students' capability. For example, Andersson Niclas argued that

a considerate mismatch is identified between the technical characteristics of the BIM curricula at universities and the process-oriented approach to BIM represented by the industry. Thus, the universities would benefit from a closer collaboration with the industry in BIM-related matters and they need to take on a strategic approach to BIM at an overall university or program level in order to avoid isolated BIM initiatives at a single course level [49].

Thus, the structure of BIM education of undergraduates in CEM majors should include curriculum content reflecting the demands and trends of the industry. The curriculum design should not only include an introduction or fundamental, intermediate, and advanced courses, but also interdisciplinary knowledge areas. Furthermore, BIM education in CEM should include the theories and methods of technology, management, economics and legal aspects, as they can be associated with CEM. Students should be equipped with industrial BIM knowledge by covering and highlighting the fundamental abilities to carry out in all four curriculum knowledge areas [26]: (a) management; (b) contract and law; (c) civil technology and (d) information technology and management in CEM or other supportive engineering domains.

\subsection{Research Framework}

Numerous approaches to incorporate industrial needs into curricula planning exist [50-55]. Some of these approaches include: (a) curriculum mapping [51] to document and visualize the curriculum learning at the programmatic level; (b) grounded theories to qualitative describe learning needs; (c) the web based system Curriculum Navigator that can explore learning attitudes towards the current curriculum [53].

QFD has been employed in engineering education to effectively analyze quality enhancement for curriculum planning in higher education using the AHP method, fuzzy logic-based method and 
integrated the Quality Function Deployment-Service Quality (QFD-SERVQUAL) model [56-61]. Sohn and Kim [59] applied QFD to revamp the existing industrial engineering curriculum by reassessing it with outcome-based learning criteria to identify the overlapping and prerequisite relations among courses. Aytac and Deniz [27] reviewed the existing curriculum and proposed a new curriculum to meet customer needs using the QFD technique [27]. Ictenbas and Eryilmaz [62] evaluated different teaching methods with regards to employers' expectation also using the QFD approach.

This research adopted the four-phase QFD to quantitatively incorporate the BIM needs of AEC industry for sustainability education (see Section 3.2). In the QFD process, it is central to convert the industrial BIM capability into the operation level of a BIM supportive curriculum during the first QFD phase. However, this research used Bloom's revised knowledge-levels (K-levels) for the importance matrix to determine the QFD relationship in order to service the cognitive process to meet curriculum assessment. Bloom's revised cognitive process highlights the learning process and covers the goal of formative assessment of a curriculum [13,18], which includes six progressive K-levels, such as remember (K1), understand (K2), apply (K3), analyze (K4), evaluate (K5) and create (K6).

This research converted industrial BIM capabilities into supportive curriculum strategies using QFD through the transition of (a) teaching quality characteristic; (b) curriculum content; and (c) teaching quality management. The overall research process is shown in Figure 3. This particular paper focuses on steps 4 (QFD Process) and 5 (Improvement Implications).

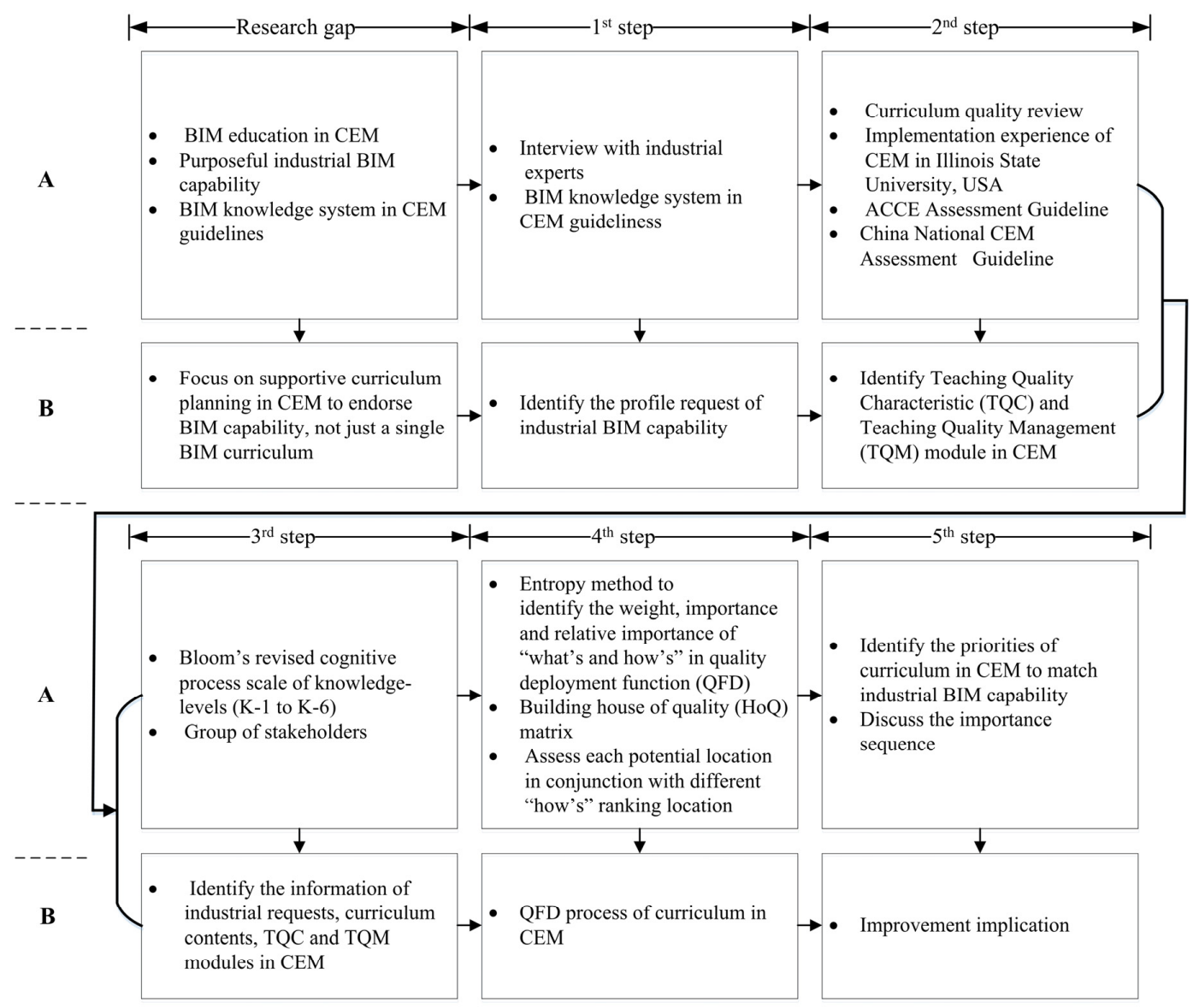

Figure 3. Research process (A) and research objectives (B).

\section{Methodology}

Unlike purely government-designed curriculums taught exclusively in schools, teaching BIM capability in the workplace allows young people to develop "hard" skills on modern up-to-date equipment, and soft skills, such as teamwork, communication and negotiation, through real-world experience. Industrial advisors along with school faculty members should evaluate technical courses 
to be taken by students, and update and align the curriculum content to meet the needs of industry [36]. Nevertheless, in this model, the authors did not consider the students as stakeholders because they are considered are consumers of the curriculum and often lack knowledge regarding the competencies.

This research applied the expert method to solicit information and included the expertise of seventeen faculty members and professionals from the construction industry. All professionals involved had an academic alliance with the Chang'an University in China and maintained a long working relationship with the faculty members of this university. These individuals were given a scoring matrix in order to assess their views on the integration of BIM into the curriculum in higher education in China. The 7 faculty members came from both from the School of Civil Engineering of Chang'an University and from the Department of Technology of Illinois State University, while the 10 came from Architectural Society of China (ASC). The 10 professionals represented large international companies in the areas of construction management and civil engineering with locations in China.

For the QFD of curriculum in CEM, we grouped the faculty members and the industry professionals to contribute to the setting and scoring of the indicators for industrial BIM capabilities including TQC and TQM in CEM using the K1-K6 scale of Bloom's revised cognitive process. Each of these individuals had more than 8 years' experience implementing industrial planning and teaching activities.

\subsection{Curriculum Teaching Quality Requirement Indicators}

\subsubsection{Teaching Quality Characteristics' (TQC) Indicators}

In order to select teaching quality characteristics (TQC) to be used in this research, a wide-ranging literature review was undertaken [19,29]. Following the literature review, a thorough process of evaluation of quality characteristics was identified and 13 TQC were established for this research project, shown in Table 1.

Table 1. Teaching quality characteristics (TQC) in CEM [19,29].

\begin{tabular}{|c|c|c|}
\hline Index & TQC & Description \\
\hline TQC1 & Teaching Arrangement & $\begin{array}{l}\text { a. Learning objectives for the class, each module, and each unit. } \\
\text { b. Designating which category of Bloom's Taxonomy each } \\
\text { objective fits. }\end{array}$ \\
\hline TQC2 & Content Structure & Match teaching contents with ACCE requirements. \\
\hline TQC3 & Prerequisites and preparation & Relationships of this course to other courses are closely related. \\
\hline TQC4 & Rationality of teaching content & $\begin{array}{l}\text { The design of lectures, assignments, projects, presentations, etc. } \\
\text { is reasonable, according to the basic requirements of BIM } \\
\text { competent training. }\end{array}$ \\
\hline TQC5 & Up-to-date information & $\begin{array}{l}\text { The teaching content is adjusted and supplemented in time } \\
\text { according to the requirement of BIM application. }\end{array}$ \\
\hline TQC6 & $\begin{array}{l}\text { The diversity of } \\
\text { teaching methods }\end{array}$ & Various teaching methods are utilized. \\
\hline TQC7 & Education Resources & $\begin{array}{l}\text { Various resources are utilized for teaching: Computer, software, } \\
\text { cloud computing, projector, online support. }\end{array}$ \\
\hline TQC8 & Advanced teaching methods & Current teaching technology is applied. \\
\hline TQC9 & Competency education & $\begin{array}{l}\text { The teaching process is closely oriented towards the cultivation } \\
\text { of BIM ability. }\end{array}$ \\
\hline TQC10 & $\begin{array}{l}\text { Interaction in teaching } \\
\text { and learning }\end{array}$ & $\begin{array}{l}\text { The teaching process emphasizes on the interaction between } \\
\text { teachers and students }\end{array}$ \\
\hline TQC11 & Flex assessment methods & $\begin{array}{l}\text { The assessment methods are flexible and diverse, not limited to } \\
\text { written tests. }\end{array}$ \\
\hline TQC12 & Prompt feedback & Reply to students' emails or questions in a timely manner. \\
\hline TQC13 & Integrated course evaluation & Teaching evaluation includes students and peers. \\
\hline
\end{tabular}




\subsubsection{Teaching Quality Management (TQM) Indicators}

After a QFD infusion, the industrial capability could be operated at the curriculum content level to meet the requirement of both curriculum planners and teachers in higher education. Curriculum content in CEM should aim at educating students, and enhance faculty and industry professionals to better meet the changing needs of industry $[36,63]$. According to the ACCE guidelines, on-campus recruiting by industry professionals, BIM software usage, industry guest lecturers, case studies, field trips, site visits, flexible classroom teaching by practitioners, quizzes, and a mandatory team exercise should be included in the contents of BIM courses [16,64-66]. Curriculum quality and classroom management [29] in CEM should not only focus on concepts and principles of BIM but also include real-life experiences. Below is a summary of teaching quality management (TQM) characteristics as developed by specialists from both Illinois State University, USA, and Chang'an University, China (Table 2).

Table 2. Teaching quality management (TQM) for superintendents and administrators.

\begin{tabular}{|c|c|c|c|c|}
\hline Index & $\begin{array}{c}\text { Course } \\
\text { Arrangement }\end{array}$ & Sub-Index & Items & Description \\
\hline \multirow[t]{3}{*}{ TQM1 } & \multirow[t]{3}{*}{$\begin{array}{l}\text { Well-structured } \\
\text { syllabus }\end{array}$} & TQM1-1 & Course introduction & $\begin{array}{l}\text { The details of a course, the conditions and methods of } \\
\text { course registration, duration of the course, course } \\
\text { delivery method, in order to help students to } \\
\text { understand the basic information of a course. }\end{array}$ \\
\hline & & TQM1-2 & Content arrangement & The fields and contents covered by the course. \\
\hline & & TQM1-3 & Teaching schedule & Define course schedule. \\
\hline \multirow{4}{*}{ TQM2 } & \multirow{4}{*}{$\begin{array}{l}\text { Teaching } \\
\text { resource and } \\
\text { material }\end{array}$} & TQM2-1 & $\begin{array}{l}\text { Preparation of } \\
\text { Textbook and } \\
\text { problem-based cases }\end{array}$ & $\begin{array}{l}\text { In order to provide learning materials to students, the } \\
\text { following items are necessary: textbook, library case } \\
\text { studies, courseware, teaching plan and references. }\end{array}$ \\
\hline & & TQM2-2 & Industrial consultant & $\begin{array}{l}\text { In addition to teachers, consider inviting industrial } \\
\text { experts or related professionals to the course. }\end{array}$ \\
\hline & & TQM2-3 & Classroom & $\begin{array}{l}\text { Identify the locations of lectures, laboratories, } \\
\text { and jobsites. }\end{array}$ \\
\hline & & TQM2-4 & $\begin{array}{l}\text { Funds and projects of } \\
\text { practical teaching }\end{array}$ & Identify funds, time, and projects for practice. \\
\hline \multirow{2}{*}{ TQM3 } & \multirow{2}{*}{$\begin{array}{l}\text { Teaching } \\
\text { content bias }\end{array}$} & TQM3-1 & Operation skill bias & $\begin{array}{l}\text { The course contents have detailed information of } \\
\text { specific professional positions and the relevant contents } \\
\text { of their operations. }\end{array}$ \\
\hline & & TQM3-2 & Management bias & $\begin{array}{l}\text { The course relates contents to marketing, operation, } \\
\text { finance and management related content. }\end{array}$ \\
\hline \multirow{6}{*}{ TQM4 } & \multirow{6}{*}{$\begin{array}{l}\text { Pedagogical } \\
\text { design }\end{array}$} & TQM4-1 & Classroom instruction & The main teaching method is lecturing. \\
\hline & & TQM4-2 & Case Study & $\begin{array}{l}\text { The teaching method is based on case teaching and } \\
\text { group discussion. }\end{array}$ \\
\hline & & TQM4-3 & Hands-on exercises & Include practice and training. \\
\hline & & TQM4-4 & Site visit & Visit companies and jobsites. \\
\hline & & TQM4-5 & Guest Speakers & Invite experts to lecture or report. \\
\hline & & TQM4-6 & $\begin{array}{l}\text { Extracurricular } \\
\text { self-study }\end{array}$ & $\begin{array}{l}\text { Encourage and include self-study through } \\
\text { online resources. }\end{array}$ \\
\hline \multirow{4}{*}{ TQM5 } & \multirow{4}{*}{ Assessment } & TQM5-1 & Final exam & Conclude the course with a written examination. \\
\hline & & TQM5-2 & Daily performance & Consider classroom performance of students. \\
\hline & & TQM5-3 & Report & $\begin{array}{c}\text { Assess social investigation reports, experiment reports, } \\
\text { or internship reports. }\end{array}$ \\
\hline & & TQM5-4 & Assignments & Assess homework assignments, projects, papers, etc. \\
\hline \multirow{4}{*}{ TQM6 } & \multirow{4}{*}{$\begin{array}{l}\text { Teaching } \\
\text { evaluation } \\
\text { module }\end{array}$} & TQM6-1 & Evaluation mechanism & Teaching evaluation mechanism is complete. \\
\hline & & TQM6-2 & Expert evaluation & Experts participate in the teaching evaluation process. \\
\hline & & TQM6-3 & Student evaluation & Alumni participate in teaching evaluation process. \\
\hline & & TQM 6-4 & Industrial evaluation & $\begin{array}{l}\text { Employers or ACCE industrial board participate in } \\
\text { teaching evaluation process. }\end{array}$ \\
\hline
\end{tabular}




\subsection{The Adaptation of the Curriculum Planning Model}

This research adopted the QFD framework of industrial engineering education to propose different curriculum planning phases [67]. Since Brackin [67] stated that all the quality characteristics in QFD had positive effects, a simple QFD matrix was adopted to present the curriculum planning process $[17,20,21]$. Operations details of the four-phase house of quality of curriculum planning are described in Figure 4:

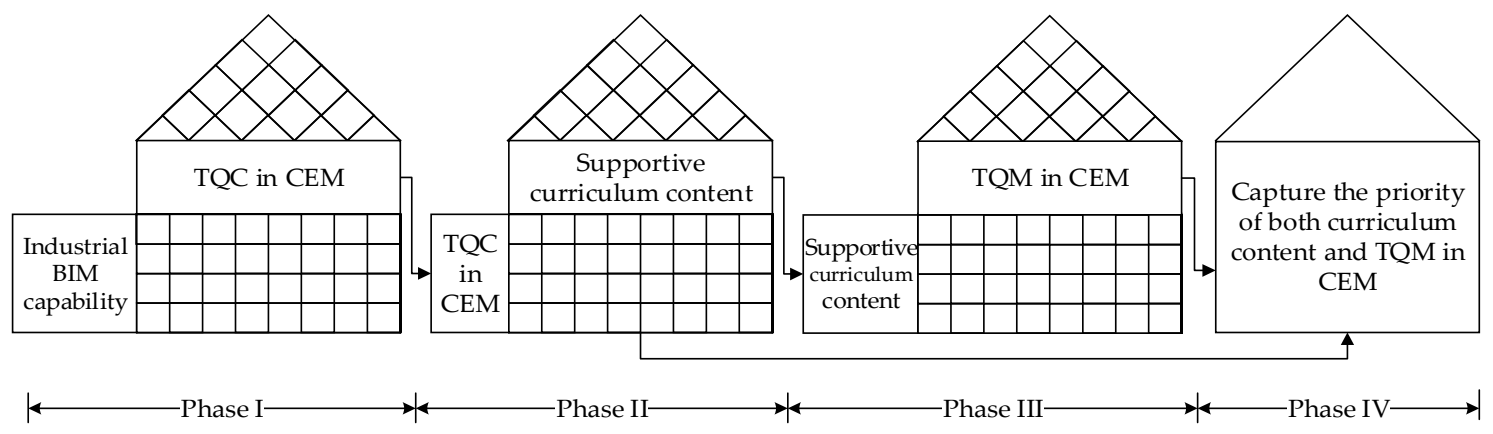

Figure 4. Curriculum planning phases using the Quality Function Deployment (QFD) method.

Phase I refers to curriculum planning, which prioritizes the industrial BIM capability best suited to deliver critical teaching quality characteristics (TQC).Phase II concerns the curriculum's design, which identifies and prioritizes the TQC to be incorporated into the supportive curriculum content in CEM. In phase III, regarding the curriculum's implementation, the preferred TQM modules and techniques are assigned to specific curriculum content in CEM. Phase IV considers the curriculum's priorities and integrates phases II and III to rank the curriculum content and TQM modules and techniques to respond the industrial BIM capability. In phase I, the weight, importance and relative importance of both industrial BIM capability and teaching quality characteristics (TQC) were calculated along with the correlation matrix $[21,67,68]$. Analog to Phase I, Phases II and III used the same steps to generate the QFD matrix.

\subsection{Validation of the Curriculum Planning Model}

\subsubsection{Justification of the Method}

This research used the entropy method to calculate the importance weight of the QFD items. It uses two layers and more than 10 indices to structure curriculum content, while comparing multiple layers and their respective indices. This research employed exclusively the entropy method to service the weights even though other research has used methods such as the Analytic Hierarchy Process (AHP). However, this research team believes that the AHP method loses its significance when involving multiple subject weight $[69,70]$.

\subsubsection{Entropy Weight}

The entropy method is an object empowerment approach that reflects the disorder degree of information in information theory and in social sciences and education related areas [71]. With this method, the weights of individual indicators are determined by calculating the entropy weight. The greater the entropy is, the smaller the corresponding entropy weight. If the entropy weight is zero, no useful information exists and its corresponding indicator may be removed. The amount of useful information that the target provides to the decision-maker is considered objective [71,72]. Using the entropy method to determine the index weights could therefore reflect the objective and realistic information of curriculum in QFD. The main four steps [71,72] are shown below: 
(1) For the formation of the evaluation matrix, suppose $m$ units and $n$ indicators are evaluated to establish the original data matrix in Equation (1).

$$
R=\left(r_{s t}\right)_{m \times n} \quad(s=1,2 \cdots, m ; t=1,2 \cdots, n)
$$

where $r_{s t}$ represents the actual value of the $t^{\text {th }}$ index of $s^{\text {th }}$ unit.

(2) The standardization of the evaluation matrix is used to normalize matrix $B$,

$B=\left(b_{s t}\right)_{m \times n} \quad(s=1,2 \cdots, m ; t=1,2 \cdots, n)$ with

$$
b_{s t}=\frac{r_{s t}-r_{\min }}{r_{\max }-r_{\min }}
$$

where $r_{\max }$ and $r_{\min }$ represent the max and min values for the evaluation unit if the indicator is the positive tropism $(+)$

$$
b_{s t}=\frac{r_{s t}-r_{\min }}{r_{\max }-r_{\min }}
$$

and if the indicator is the negative tropism (-)

$$
b_{s t}=\frac{r_{\max }-r_{s t}}{r_{\max }-r_{\min }}
$$

(3) Then, the entropy of the system can be calculated as:

$$
H_{t}=-\left(\sum_{s=1}^{m} f_{s t} \ln f_{s t}\right) / \ln m \quad(s=1,2 \cdots, m ; t=1,2 \cdots n)
$$

where $f_{s t}=b_{s t} / \sum_{s=1}^{m} b_{s t}$, if $f_{s t}=0$, then redefine the $f_{s t}$ as

$$
f_{s t}=\left(1+b_{s t}\right) / \sum_{s=1}^{m}\left(1+b_{s t}\right)
$$

(4) Finally, the entropy weight can be calculated as

$$
w=\left(\omega_{t}\right)_{1 \times n}, \omega_{t}=\left(1-H_{t}\right) /\left(n-\sum_{t=1}^{n} H_{t}\right) \text { with } \sum_{t=1}^{n} \omega_{t}=1
$$

\subsubsection{Importance, Relative Importance and Correlation Matrix}

Once the weights of "how's and what's" of the QFD matrix were generated, the researchers built the House of Quality (HoQ). We can now complete the HoQ by calculating the index importance for the "how's and what's". The index importance $p_{t}$ could be calculated in Equation (8).

$$
p_{t}=\omega_{t} \times \sum_{n^{e}=1}^{N} t_{n^{e}} / N
$$

where $p_{t}$ refers to the $t^{\text {th }}$ index importance, $\omega_{t}$ refers to entropy weight of the $t^{t h}$ index, $t_{n}$ refers to the score of $n^{\text {th }}$ decision-maker for the $t^{\text {th }}$ index, and $n^{e}=(1, . ., N)$.

Select the modular $p_{z}$ among the importance $p_{t}$ as unit 1 to generate the relative importance $\bar{p}_{t}$ of the $t^{\text {th }}$ index, shown in Equation (9).

$$
\bar{p}_{i}=\frac{p_{t}}{p_{z}}
$$


As to the correlation matrix in QFD of curriculum in CEM, the researchers used the common method of Pearson correlation $\rho_{X Y}$ to generate the coefficient $[73,74]$, as shown in Equation (10):

$$
\begin{gathered}
\rho_{X Y}=\frac{\operatorname{cov}(X, Y)}{\sqrt{\operatorname{cov}(X, X) \cdot \operatorname{cov}(Y, Y)}}=\frac{\sum(X-\bar{X})(Y-\bar{Y})}{\sqrt{\sum_{X \sum}(X-\bar{X})^{2} \sum(Y-\bar{Y})^{2}}} \\
=\frac{\sum X Y-\frac{\sum \sum Y}{17}}{\sqrt{\left(\sum X^{2}-\frac{\left(\sum X\right)^{2}}{N}\right)\left(\sum Y^{2}-\frac{\left(\sum Y\right)^{2}}{N}\right)}}
\end{gathered}
$$

where $X$ refers to "what's" and $Y$ refers to "how's" in the QFD matrix, $\sum X Y=\sum_{n=1}^{N} X_{n} Y_{n}, \sum X=\sum_{n=1}^{N} X_{n}$, $\sum Y=\sum_{n=1}^{N} Y_{n}, \sum X^{2}=\sum_{n=1}^{N} X_{n}^{2}$, and $\sum Y^{2}=\sum_{n=1}^{N} Y_{n}^{2}$

The larger the absolute $\rho_{X Y}$, the stronger the correlation. The scale of correlation evaluation is shown in the Table 3.

Table 3. The criteria of correlation evaluation, adopted from Creswell [74] and Lehmann [73].

\begin{tabular}{cccccc}
\hline Absolute Coefficient & $\mathbf{0 . 8 - 1 . 0}$ & $\mathbf{0 . 6 - 0 . 8}$ & $\mathbf{0 . 4 - 0 . 6}$ & $\mathbf{0 . 2 - 0 . 4}$ & $\mathbf{0 . 0 - 0 . 2}$ \\
\hline $\begin{array}{c}\text { Correlation Extent } \\
\text { Label }\end{array}$ & $\begin{array}{c}\text { stronger } \\
(\mathcal{O}=\text { strong }\end{array}$ & $\begin{array}{c}\text { strong } \\
\mathbf{0}=\text { moderate }\end{array}$ & $\begin{array}{c}\text { weak } \\
\text { = weak }\end{array}$ & $\begin{array}{c}\text { weaker } \\
\text { NO consideration }\end{array}$ \\
\hline
\end{tabular}

\section{Results}

\subsection{Phase I}

This research implemented Equations (1)-(7) of the entropy method to generate the entropy weight of industrial BIM capability. It also used 13 TQC indices in CEM as shown in Figure 5.

\begin{tabular}{|l|c|c|c|c|c|c|c|c|c|c|c|c|c|c|c|c|c|}
\hline $\begin{array}{l}\text { BIM } \\
\text { capability }\end{array}$ & TQC & TQC2 & TQC3 & TQC4 & TQC5 & TQC6 & TQC7 & TQC8 & TQC9 & TQC10 & TQC11 & TQC12 & TQC13 Entropy & $\begin{array}{l}\text { Timportance } \\
\text { weight }\end{array}$ & $\begin{array}{l}\text { Relative } \\
\text { importance }\end{array}$ \\
\hline OA-BIM & $\Delta$ & $\Delta$ & $\Delta$ & & & $\Delta$ & & $\Delta$ & $\bullet$ & $\bullet$ & & $\bullet$ & & 0.114 & 0.288 & 0.479 & 6 \\
\hline PA-BIM & & & & $\Delta$ & & $\Delta$ & & & & & $\bullet$ & $\Delta$ & $\Delta$ & 0.114 & 0.545 & 0.907 & 4 \\
\hline AA-BIM & & & & & $\Delta$ & & & $\Delta$ & & $\Delta$ & & & $\bullet$ & 0.215 & 0.656 & 1.093 & 3 \\
\hline BA-BIM & & & $\bullet$ & $\Delta$ & & & & $\bullet$ & & & & $\Delta$ & $\bullet$ & 0.134 & 0.370 & 0.615 & 5 \\
\hline MA-BIM & $\Delta$ & $\bullet$ & & & & & $\Delta$ & & $\Delta$ & $\Delta$ & & & & 0.215 & 1.052 & 1.752 & 1 \\
\hline IA-BIM & & & & $\Delta$ & & & $\Delta$ & & & & & & & 0.208 & 0.931 & 1.551 & 2 \\
\hline Entropy weight & 0.094 & 0.063 & 0.071 & 0.065 & 0.081 & 0.046 & 0.101 & 0.049 & 0.108 & 0.064 & 0.091 & 0.069 & 0.099 & & & & \\
\hline Importance & 0.288 & 0.225 & 0.226 & 0.206 & 0.290 & 0.177 & 0.345 & 0.194 & 0.412 & 0.218 & 0.341 & 0.267 & 0.325 & & & & \\
\hline $\begin{array}{l}\text { Relative } \\
\text { importance }\end{array}$ & 0.836 & 0.653 & 0.655 & 0.598 & 0.839 & 0.512 & 1.000 & 0.561 & 1.195 & 0.632 & 0.989 & 0.774 & 0.943 & & & & \\
\hline Rank & 6 & 9 & 8 & 11 & 5 & 13 & 2 & 12 & 1 & 10 & 3 & 7 & 4 & & & & \\
\hline
\end{tabular}

Figure 5. House of Quality (HoQ) of industrial BIM capability and TQC in CEM with $\triangle=$ weak, - = moderate, $(\mathrm{O}=$ strong; and the "what's" = industrial BIM capability including OA-BIM, PA-BIM and so on and the "how's" = Curriculum TQC.

Figure 5 identifies MA-BIM, AA-BIM and IA-BIM as the top BIM capability indicators. In order to convert the BIM capabilities into the TQC in CEM, the researchers will focus on the top four aspects of teaching quality indicators (TQCs 7, 9, 11 and 13). Industrial BIM capability indices were assigned to different TQC requirements in order to enhance the infusion process in higher education. In particular, MA-BIM should focus attention on the correlation with TQC2, BA-BIM with TQCs 8 and 13, OA-BIM with TQCs 9, 10 and 12, AA-BIM with TQC13. Phase I was completed to convert industrial BIM capability into TQC in CEM to build a solid foundation to analogy the following two QFD processes in CEM. 


\subsection{Phase II and III}

According to the CEM undergraduate curriculum accredited by the ACCE in China, curriculum content should include system cognitive knowledge such as civil engineering technology, flow construction, construction cost, and construction law and management. This research identified two supportive domains in CEM curriculum to infuse industrial BIM capability: Flow construction (FC, Table 4) and construction cost (CC, Table 5).

Table 4. Flow construction (FC) in CEM.

\begin{tabular}{|c|c|c|c|}
\hline Code & Curriculum Unit & Knowledge Point & Description \\
\hline \multirow{5}{*}{ FC1 } & \multirow{5}{*}{ Introduction } & FC1-1 & Characteristics of engineering construction \\
\hline & & FC1-2 & Basic principle of construction organization plan \\
\hline & & FC1-3 & Raw data survey \\
\hline & & FC1-4 & Preparation work before construction \\
\hline & & FC1-5 & Classification of construction organization design \\
\hline \multirow{3}{*}{ FC2 } & \multirow{3}{*}{$\begin{array}{l}\text { Basic principles of } \\
\text { workflow }\end{array}$} & FC2-1 & Concept of flow construction \\
\hline & & FC2-2 & Flow construction parameter \\
\hline & & FC2-3 & Classification and organization of flow construction \\
\hline \multirow{6}{*}{ FC3 } & \multirow{6}{*}{$\begin{array}{c}\text { Program } \\
\text { evaluation and } \\
\text { review technique } \\
(\text { PERT })\end{array}$} & FC3-1 & Drawing of single code and dual code \\
\hline & & FC3-2 & Computing time parameter of network graph \\
\hline & & FC3-3 & Time scale network plan \\
\hline & & FC3-4 & Overlapping network plan \\
\hline & & FC3-5 & PERT optimization \\
\hline & & FC3-6 & PERT planning control \\
\hline \multirow{6}{*}{ FC4 } & \multirow{6}{*}{$\begin{array}{l}\text { Construction } \\
\text { workflow design of } \\
\text { unit projects }\end{array}$} & FC4-1 & $\begin{array}{l}\text { The basis and contents of construction organization } \\
\text { in project units }\end{array}$ \\
\hline & & FC4-2 & Project profile and construction conditions \\
\hline & & FC4-3 & Construction scheme \\
\hline & & FC4-4 & Schedule plan in project units \\
\hline & & FC4-5 & Resource requirement plan \\
\hline & & FC4-6 & Total design of project units \\
\hline \multirow{5}{*}{ FC5 } & \multirow{5}{*}{$\begin{array}{l}\text { Total design of } \\
\text { construction } \\
\text { workflow }\end{array}$} & FC5-1 & Design procedure and basis of total design \\
\hline & & FC5-2 & Construction deployment \\
\hline & & FC5-3 & Total schedule of construction \\
\hline & & FC5-4 & Total design plan for construction \\
\hline & & FC5-5 & Technical and economic index \\
\hline
\end{tabular}

Table 5. Construction cost (CC) in CEM.

\begin{tabular}{lccl}
\hline Code & Curriculum Unit & Knowledge Point Code & \multicolumn{1}{c}{ Description } \\
\hline \multirow{4}{*}{ CC1 } & $\begin{array}{c}\text { Basic knowledge } \\
\text { of project } \\
\text { evaluation }\end{array}$ & CC1-1 & $\begin{array}{l}\text { The conception of project valuation } \\
\text { Project evaluation process } \\
\text { Project valuation basis }\end{array}$ \\
& & CC1-2 & Project investment composition \\
& & CC2-3 & The composition of equipment purchase cost \\
CC2 & Project cost & CC2-2 & The cost composition of construction installation \\
& structure & CC2-3 & The cost composition of other parts in construction \\
& & CC2-4 & Budget reserve and interest in construction \\
\hline \multirow{4}{*}{ CC3 } & Project quota & CC2-5 & Concept and principle of project quota \\
& & CC3-2 & Method of compiling project quota \\
& & CC3-3 & Consumption method of construction engineering, \\
& & CC3-4 & Unit price of construction engineering, material, machine \\
& & CC3-5 & Establishment of project quota \\
\hline
\end{tabular}


Table 5. Cont.

\begin{tabular}{|c|c|c|c|}
\hline Code & Curriculum Unit & Knowledge Point Code & Description \\
\hline \multirow{6}{*}{ CC4 } & \multirow{6}{*}{$\begin{array}{l}\text { Bill of quantities } \\
\text { (BoQ) }\end{array}$} & CC4-1 & General guideline \\
\hline & & CC4-2 & Remote monitoring and control \\
\hline & & CC4-3 & BoQ compilation of civil work \\
\hline & & CC4-4 & BoQ compilation of service building \\
\hline & & CC4-5 & BoQ compilation of electricity works \\
\hline & & CC4-6 & BoQ calculation of other works \\
\hline \multirow{4}{*}{ CC5 } & \multirow{4}{*}{$\begin{array}{l}\text { Investment } \\
\text { estimation }\end{array}$} & CC5-1 & Basic principles of investment estimation \\
\hline & & CC5-2 & Characteristics of investment estimation \\
\hline & & CC5-3 & The role of investment estimation \\
\hline & & CC5-4 & Common methods of estimating investment \\
\hline \multirow{5}{*}{ CC6 } & \multirow{5}{*}{$\begin{array}{l}\text { Budget based on } \\
\text { concept design }\end{array}$} & CC6-1 & Basic principles of concept design budget \\
\hline & & CC6-2 & Characteristics of concept design budget \\
\hline & & CC6-3 & Functions of concept design budget \\
\hline & & CC6-4 & Contents of concept design budget \\
\hline & & CC6-5 & Compilation and review of concept design budget \\
\hline \multirow{5}{*}{ CC7 } & \multirow{5}{*}{$\begin{array}{l}\text { Budget based on } \\
\text { construction } \\
\text { drawings }\end{array}$} & CC7-1 & Basic principles of construction drawings budget \\
\hline & & CC7-2 & Characteristics of construction drawings budget \\
\hline & & CC7-3 & Functions of construction drawings budget \\
\hline & & CC7-4 & Contents of construction drawings budget \\
\hline & & CC7-5 & Compilation and review of construction drawings budget \\
\hline \multirow{3}{*}{$\mathrm{CC} 8$} & \multirow{3}{*}{$\begin{array}{l}\text { Bidding control } \\
\text { price and project } \\
\text { tender offer }\end{array}$} & CC8-1 & Compiling Methods \\
\hline & & $\mathrm{CC} 8-2$ & Project tender offer method \\
\hline & & CC8-3 & Project bid analysis \\
\hline \multirow{6}{*}{ CC9 } & \multirow{6}{*}{ Project settlement } & CC9-1 & Project change and contract price adjustment \\
\hline & & CC9-2 & Project claim \\
\hline & & CC9-3 & Definition of project settlement \\
\hline & & CC9-4 & Plan for project settlement \\
\hline & & CC9-5 & Type for project settlement \\
\hline & & CC9-6 & Method for project settlement \\
\hline
\end{tabular}

\subsubsection{Curriculum I: Construction Cost}

Phase II: HoQ—curriculum contents and TQC

Using Equations (1)-(7), the weights of "what's"(TQC in CEM) and "how's"(Curriculum TCQ) were generated. In addition, the related coefficient was generated by Equations (8)-(10). The HoQ of $\mathrm{CC}$ and TQC is shown in Figure 6:

As shown in Figure 6, some curriculum contents of CC should be focused on corresponding TQC in CEM to enhance undergraduate BIM capability education, including the principles of bill of quantities (code CC4-2 in Table 5). Further attention should be given on diversity of teaching methods (code TQC6 in Table 5),components of construction expenses (codes CC2-2 and CC2-4 in Table 5) and the cohesiveness of teaching contents (codes TQC 3 and TQC 2 in Table 5).Some curriculum contents of CC should include unit price of CC (code CC3-4 in Table 5) with a focus on teaching diversity (code TQC 6 in Table 5); and the preparation of bill of quantities (codes CC4-1, 4-3 and CC8-1 in Table 5) with a focus on scientific and rational design of teaching content (code TQC 4 in Table 5).

Phase III HoQ—curriculum contents and TQM modules

With regards to TQM in Figure 7, some contents of CC should focus strongly on specific requirements of good teaching quality. For example, Investment estimation (code CC5-2 in Table 5) should be taught with the cognizance of operating skill bias (code TQM3-1 in Table 2), budget planning of construction (code CC7-5 in Table 5) should be taught using the richness of teaching content (code TQM1-2 in Table 2), and project bidding and analysis (code CC8-3 in Table 5) should be taught using case studies (code TQM4-4 in Table 2). 


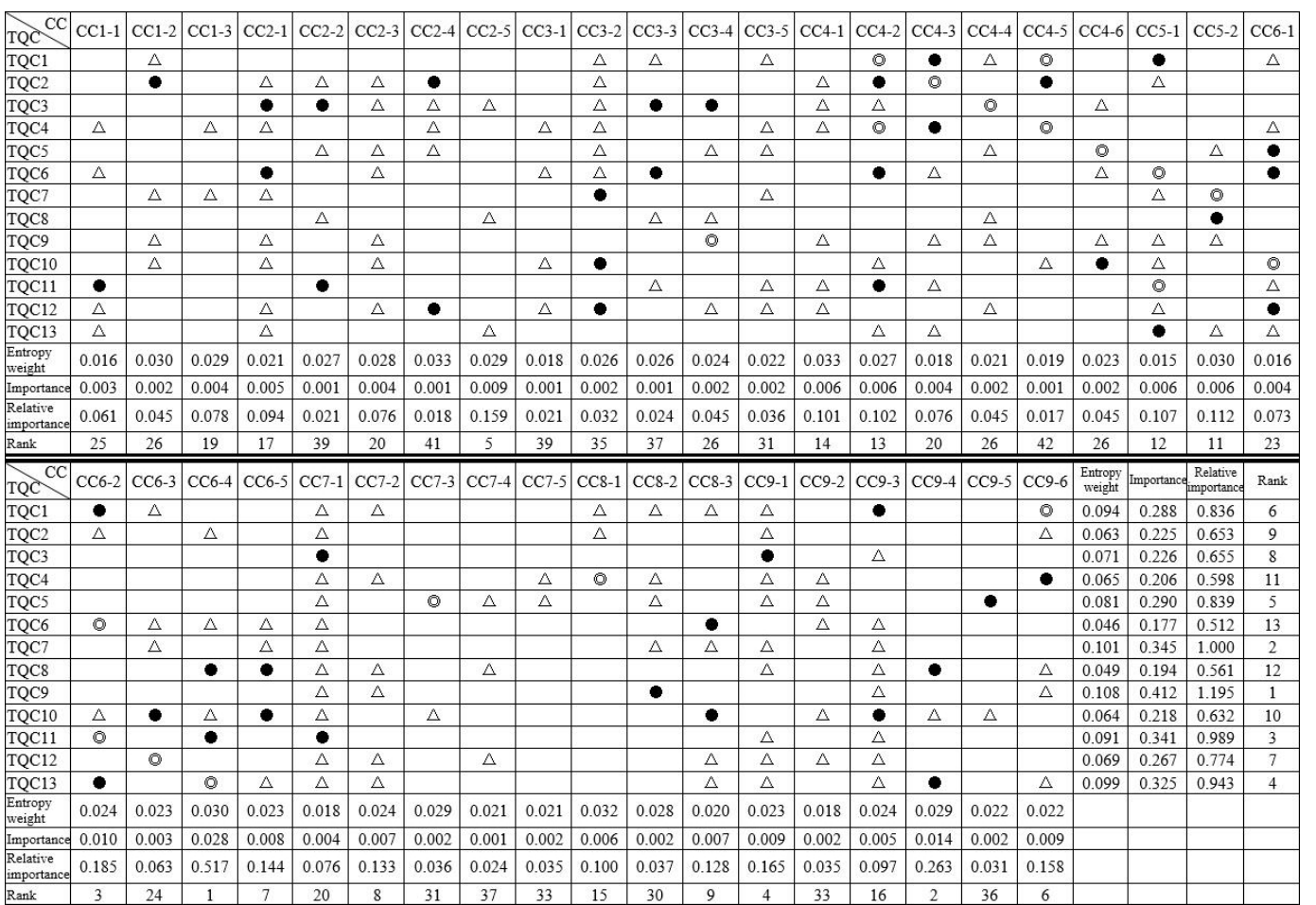

Figure 6. HoQ of CC and TQC with $\triangle$ = weak, $\bullet=$ moderate, $(\mathcal{O}=$ strong; and the "what's"= Teaching Quality Characteristic (TQC) and the "how's" = Curriculum content of CC.

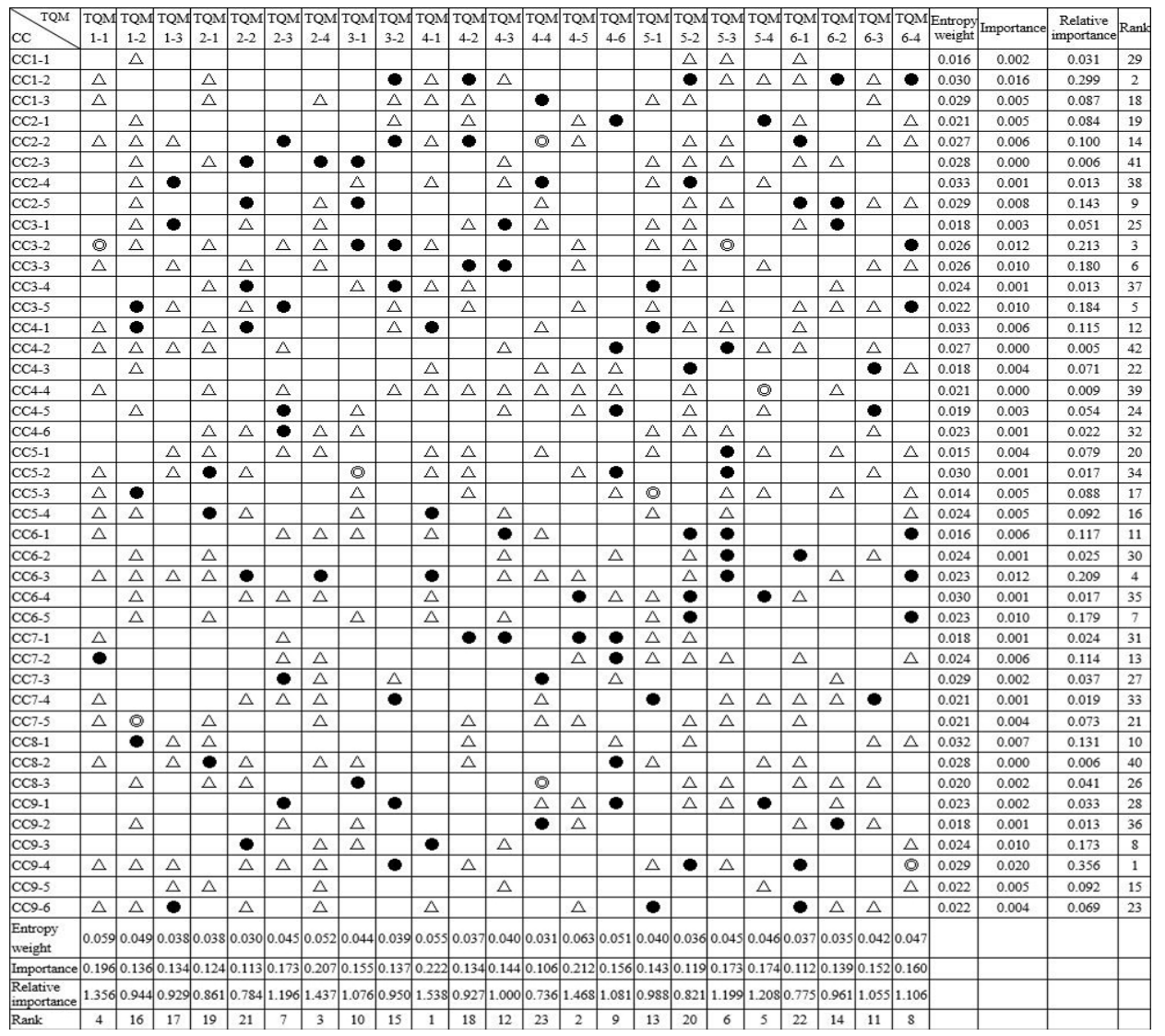

Figure 7. HoQ of $\mathrm{CC}$ and TQM with $\triangle$ = weak, $\bullet=$ moderate, $(\mathcal{O}=$ strong; and the "what's" = Curriculum content of CC and the "how's" = TQM. 


\subsubsection{Curriculum II: Flow Construction}

Phase II HoQ—curriculum contents and TQC

With regard to TQC in Figure 8, curriculum content of flow construction should use system design of case studies (codes TQC 1, TQC2 and TQC3 in Table 1).

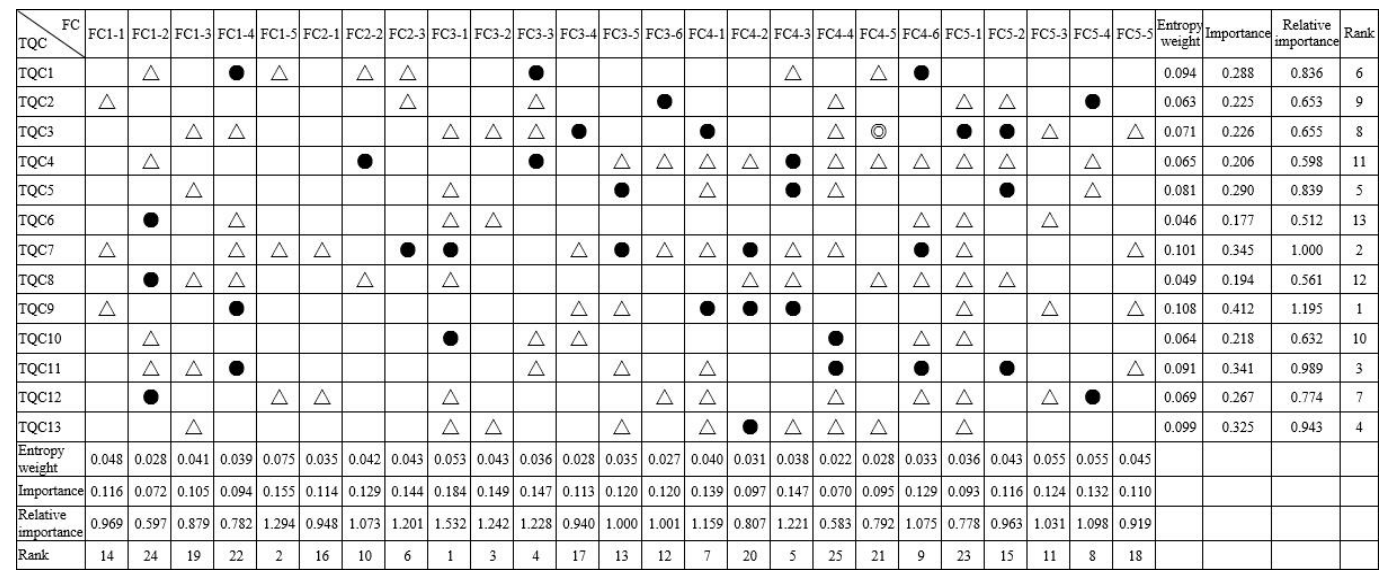

Figure 8. HoQ of flow construction and TQC. Source: compiled by the authors. $\triangle=$ weak, $\bullet=$ moderate, (O) = strong; and the "what's" = Teaching Quality Characteristic (TQC) and the "how's" = curriculum content of Flow Construction (FC).

Phase III HoQ matrix—curriculum content and TQM modules

With regards to TQM in Figure 9, curriculum contents of FC should enhance the teaching quality to strengthen the base for BIM training. Construction planning (code FC4-3 in Table 4) and Program evaluation and review technique(PERT) optimization (code FC3-5 in Table 4) should enhance the improvement of student assessment (code TQM6-3 in Table 2). The concept of flow construction (code FC2-1 in Table 4) should use case studies (code TQM4-2 in Table 2), the parameter of FC (code FC2-2 in Table 4) could use simulation training (code TQM4-3 in Table 2) and the schedule and classify of FC (code FC2-3 in Table 4) should provide on on-site teaching (code TQM4-4 in Table 2).

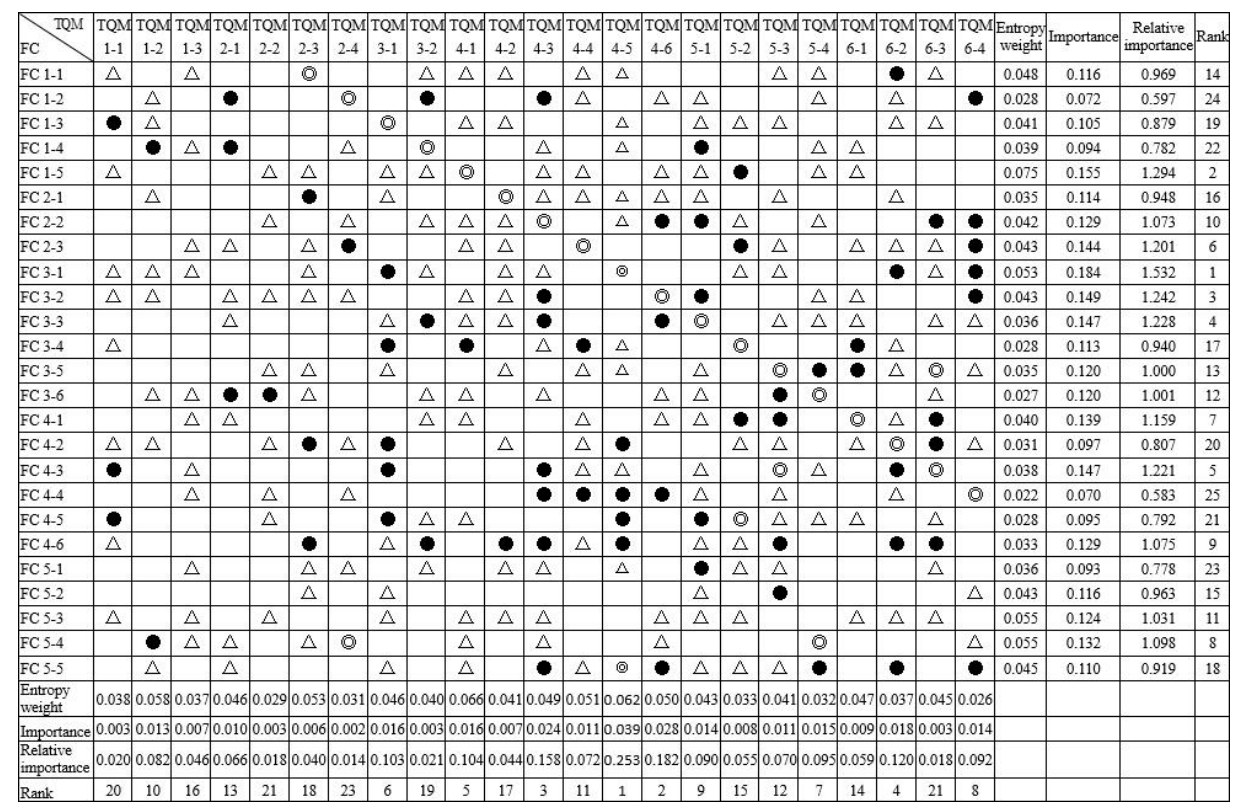

Figure 9. HoQ of $\mathrm{FC}$ and TQM with $\triangle$ = weak, $\bullet=$ moderate, $(\mathrm{O}=$ strong; and the "what's" = Curriculum content of FC and the "how's" = TQM. 


\subsection{Phase IV: Ranking of the Importance of the Curriculum and TQM Modules}

The importance of knowledge points in CEM such as CC and FC was determined by generating the corresponding coefficients in the relational HoQ matrix during phases I, II and III. It was easy to rank the importance of knowledge points and sub-TQM technology. As to knowledge units composed by knowledge points, and TQM modules composed by sub-TQM technology, this research employed the cumulative importance method of knowledge points in each knowledge unit in the curriculum to capture the priority of curriculum units, which was also equal to ranking the importance of TQM modules.

For example, taking the case of importance $I_{1}$ of knowledge unit 1 in the flow construction in HoQ matrix during phase II, knowledge unit 1 was composed by five knowledge points, and its importance $I_{1}$ could be shown in Equation (11).

$$
I_{1}=i_{11}+i_{12} \cdots i_{15}
$$

where $i_{11}, i_{12}, \cdots i_{15}$ refer to the importance of five knowledge points 1-1, 1-2, 1-3, 1-4 and 1-5. So,

$$
I_{1}=0.119067873+0.071684233+0.105435318+0.093844086+0.155257137=0.545288647 \text {. }
$$

For the remaining knowledge units and TQM modules the corresponding total importance could be calculated, which in turn can be ranked according to its total importance. A top 10 ranking summary of two curriculums are shown in Tables 6 and 7 respectively.

Table 6. Top 10 contents ranking of two curriculums in CEM.

\begin{tabular}{cccccccc}
\hline \multicolumn{3}{c}{ Curriculum1:ConstructionCost (CC) } & \multicolumn{3}{c}{ Curriculum2:FlowConstruction (FC) } \\
\hline Rank & $\begin{array}{c}\text { Knowledge } \\
\text { Point }\end{array}$ & $\begin{array}{c}\text { Knowledge } \\
\text { Unit }\end{array}$ & $\begin{array}{c}\text { Total } \\
\text { Importance }\end{array}$ & Rank & $\begin{array}{c}\text { Knowledge } \\
\text { Point }\end{array}$ & $\begin{array}{c}\text { Knowledge } \\
\text { Unit }\end{array}$ & $\begin{array}{c}\text { Total } \\
\text { Importance }\end{array}$ \\
\hline 1 & CC 3-3 & CC unit 9 & 0.512 & 1 & FC 3-1 & FC unit 3 & 0.833 \\
2 & CC 4-1 & CC unit 4 & 0.472 & 2 & FC 1-5 & FC unit 4 & 0.676 \\
3 & CC 9-4 & CC unit 2 & 0.471 & 3 & FC 3-2 & FC unit 5 & 0.574 \\
4 & CC 2-4 & CC unit 7 & 0.431 & 4 & FC 3-3 & FC unit 1 & 0.545 \\
5 & CC 7-3 & CC unit 3 & 0.415 & 5 & FC 4-3 & FC unit 2 & 0.386 \\
6 & CC 2-2 & CC unit 6 & 0.296 & 6 & FC 2-3 & & \\
7 & CC 2-5 & CC unit 5 & 0.215 & 7 & FC 4-1 & & \\
8 & CC 9-3 & CC unit 8 & 0.207 & 8 & FC 5-4 & & \\
9 & CC 7-4 & CC unit 1 & 0.202 & 9 & FC 4-6 & & \\
10 & CC 1-2 & & & 10 & FC 2-2 & &
\end{tabular}

Table 7. Top 10 TQM ranking for two curriculums in CEM.

\begin{tabular}{cccccccc}
\hline \multicolumn{3}{c}{ Curriculum1:ConstructionCost (CC) } & \multicolumn{3}{c}{ Curriculum2:FlowConstruction (FC) } \\
\hline Rank & $\begin{array}{c}\text { Sub-TQM } \\
\text { Technology }\end{array}$ & TQM Module & $\begin{array}{c}\text { Total } \\
\text { Importance }\end{array}$ & Rank & $\begin{array}{c}\text { Sub-TQM } \\
\text { Technology }\end{array}$ & TQM Module & $\begin{array}{c}\text { Total } \\
\text { Importance }\end{array}$ \\
\hline 1 & TQM 4-1 & TQM module 4 & 0.974 & 1 & TQM 4-5 & TQM module 4 & 1.023 \\
2 & TQM 4-5 & TQM module 2 & 0.617 & 2 & TQM 1-2 & TQM module 5 & 0.588 \\
3 & TQM 2-4 & TQM module 5 & 0.608 & 3 & TQM 4-1 & TQM module 2 & 0.574 \\
4 & TQM 1-1 & TQM module 6 & 0.562 & 4 & TQM 2-1 & TQM module 6 & 0.532 \\
5 & TQM 5-4 & TQM module 1 & 0.466 & 5 & TQM 4-6 & TQM module 1 & 0.461 \\
6 & TQM 5-3 & TQM module 3 & 0.292 & 6 & TQM 5-1 & TQM module 3 & 0.299 \\
7 & TQM 2-3 & & & 7 & TQM 6-3 & & \\
8 & TQM 6-4 & & 8 & TQM 3-1 & & \\
9 & TQM 4-6 & & 9 & TQM 2-3 & & \\
10 & TQM 3-1 & & 10 & TQM 4-4 & & \\
\hline
\end{tabular}

As shown in Table 6, the top three knowledge units were (1) Project Settlement; (2) BoQ; and (3) Project Cost Structure. The top knowledge units for the construction curriculum were (1) PERT 
and (2) construction workflow design of unit projects. Some knowledge points should be used as the main support for CEM undergraduate BIM training in CC curriculums: (1) construction consumption; (2) the principles of BoQ; (3) CC delivery planning and implementation; (4) project expense constitutes; and (5) the function of construction budget. In FC curriculums, these knowledge points are (1) single code and double code network diagrams; (2) construction design classification; (3) network diagrams parameter calculation and planning; and (4) construction scheme.

As shown in Table 7, the top three TQM modules for CC and FC curriculums were (a) pedagogical design; (b) teaching resource and material and (c) curriculum assessment. However, for CC, sub-TQM technologies such as industrial advisor, lecture reporting, real-life experience and fund support, curriculum introduction and curriculum report play important roles in enhancing the integration between industrial BIM capability and curriculum content. As for FC, lecture reporting, curriculum content planning, class teaching, out of class self-learning and case resource pool, they all contributed positively to the improvement of CEM undergraduate BIM capability.

\subsection{Discussion}

QFD is a common structured method for CEM curriculum planning. It enables focus groups of industrial professionals and academics to specify the needs for industrial BIM capability. QFD then continues to progressively and systematically build a matrix between each proposed "how's and what's" in terms of its impact on integrating industrial demands into the academic curriculum. QFD attempts to instill qualities in students to smoothly transition from school to work after graduating from their respective universities.

Although the QFD technique has gained growing acceptance for curriculum development in higher education $[17,18,20,29]$, implementing QFD to analyze the supportive relationship between BIM education and related curriculum development in CEM is a new approach for TQM module development at the operational level.

For CEM undergraduate students, the capability requirements from the construction industry is rather comprehensive and includes basic technology skills that should be taught in a single BIM courses, including (a) operation ability of BIM software (OA-BIM); (b) production ability of BIM models (PA-BIM) and (c) application ability of BIM models (AA-BIM); (d) building ability of BIM application environments (BA-BIM); (e) management ability of BIM projects (MA-BIM); and (f) integration ability of BIM businesses (IA-BIM). According to the ACCE guidelines, all these capabilities need to be included in the related curriculum.

Universities shape students' capabilities mainly by focusing on two important aspects, (a) curriculum content and (b) teaching methodologies. This research proposed a four-phase QFD process in CEM supportive of the BIM curriculum to address these two areas in response to the voice of industrial professionals and faculty members in higher education.

Identifying the individual weight of each content area is a critical precursor to analyze the coefficients and to capture the priority of the QFD matrix between "how's and what's" in CEM curriculum. Numerous studies applied the AHP and fuzzy mixed methods in the past to analyze the QFD matrix $[18,21,75,76]$. This paper innovatively used the entropy method and a scale of Bloom's revised cognitive processes (K1-K6) to generate the weights of "how's and what's" by maintaining objectivity of weight assessment using a variety of indices. Additionally, this research summarized the top knowledge areas and TQM modules to enhance teaching quality in CEM. At the same time, the two curriculums of the four main knowledge areas provided by the Chinese CEM guidelines, namely, construction cost and flow construction, shed light on the QFD process implementation.

Curriculum I on FC showed that undergraduate students should embrace network planning technologies and construction optimization methodologies for a better development of BIM models (PA-BIM) and enhancing their application ability. In the process of curriculum teaching, FCF should be prone to employing BIM, and team learning to show the infusion of knowledge points including (a) principles and content (code FC4-1 in Table 4); (b) resource planning (code FC4-5 in Table 4) and 
(c) total construction planning (code FC5-4 in Table 4). Some knowledge points should be enhanced with real life experiences and on-site teaching such as flow construction and application (code FC2-3 in Table 4), network drawing (code FC3-1 in Table 4), network optimization (code FC3-5 in Table 4), project overview and construction conditions (code FC4-2 in Table 4) and total planning in unit construction (code FC4-6 in Table 4) (seen the corresponding HoQ in Phase II). With regards to sub-TQM technology, flow construction should pay close attention to apply (a) BIM teaching projects and case studies; (b) industrial lectures and reporting, and (c) homework assignments and open lab operations with BIM software as seen the corresponding HoQ in Phase III.

Curriculum II on CC showed that curriculum content should highlight the principles of BoQ, construction consumption, CC delivery planning and implementation to respond to the profile request of cost management, project and integration management to successfully implement construction projects (as seen in HoQ in Phase II). At the same time, different sub-TQM technology should be assigned to strengthen and promote a cognitive understanding of $\mathrm{CC}$, such as finance content (code TQM 3-2 in Table 2) to the formulation of CC (code CC 3-2 in Table 5), and industrial advisement (code TQM 2-2 in Table 2) to reserve funds (code CC 2-5 in Table 5), which were also seen in the HoQ in Phase III.

\section{Conclusions}

Trends are emerging that transform engineering education to include sustainability and BIM as driving curricula forces within AEC industries. This paradigm shift in higher education has set new challenges to develop new competencies that include BIM capability and meet the emerging industry needs. The proposed approach presents a systematic way to address challenges of industrial BIM needs and sustainability education in a real-world scenario.

This research addresses curriculum planning by considering major components of BIM education, such as TQC and TQM modules. A four-phase QFD framework incorporating these indicators has been developed by applying the entropy method and a scale from Bloom's revised cognitive process to evaluate the HoQ matrix between "how's and what's."

The results show a supportive relationship between the four areas. The outcomes of this study provide information on the impact related supportive curriculum in CEM would have on the undergraduate BIM education. Additionally, this research summarizes the top curriculum knowledge units and TQM modules in order to capture the priorities of curriculum planning, which indicates that a feasible and practical approach in both curriculum contents development and teaching quality management can be achieved in higher education. In particular, with regard to the top 10 contents area rankings of curriculums (FC and CC) in CEM, the concentration on these two content areas demonstrated that the attention of curriculum development should focus on three objects (a) pedagogical design; (b) teaching resource and material and (c) curriculum assessment.

The discussed content areas also suggested that the proposed approach can be used to evaluate the mutually supportive relationships in curriculum planning especially when collaborating with industry. We have therefore demonstrated that the proposed QFD framework can be used to solve various types of knowledge domain challenges that impact undergraduate construction related education.

The highlight of this research is the application of the proposed framework to a large-scale curriculum development process in CEM in higher education. The proposed framework can be employed to a wide range of curriculum planning and design or to similar engineering programs. Moreover, the model can be used as a basis for further extensions such as applying enhanced QFD to recognize dynamic industrial needs to include more complex curriculum requirements into curriculum subsystems and assemble those with supporting deployment matrices and concept selection matrices.

Acknowledgments: This research is supported by the National Natural Science Fundation of China (No. 71301013); Humanity and Social Science Program Foundation of Ministry of Education of China (No. 13YJA790150); China ASC Fund (No. asc-kt2014022 and No. asc-kt2014023); China Scholarship Council; Shaanxi Nature Science Fund (No. 2014JM2-7140); Shaanxi Social Science Fund (No. 2014HQ10, No. 2015Z071, No. 2015Z075and No. 2016Z047); 
Xi'an Science Technology Burea Fund(No. CXY1512(2)); Special Fund for Graduate Student Education Reform of Central College, Chang'an University (No. jgy16062); Special Fund for Basic Scientific Research of Central College (Humanities and Social Sciences), Chang'an University (No. 0009-2014G6285048, No. 310828155031, No. 310828160661 and No. 310828160663$)$.

Author Contributions: Jingxiao Zhang and Hui Li conducted the interviews, analyzed the data and contributed to drafting the paper. Jingxiao Zhang and Hui Li contributed to the concept and design of the paper, Klaus Schmidt contributed useful advice and modified the draft. Finally, Jingxiao Zhang and Klaus Schmidt were in charge of the final version of the paper.

Conflicts of Interest: The authors declare no conflict of interest.

\section{Abbreviations}

ACCE

$\mathrm{AEC} / \mathrm{FM}$

BIM

CEM

TQC

TQM

QFD

HoQ

China ASC

FC

$\mathrm{CC}$
American Council for Construction Education

Architectural, Engineering, Construction, and Facility Management

Building information model

Civil Engineering and Management

Teaching Quality Characteristics

Teaching Quality Management

Quality Deployment Function

House of Quality

China Architectural Society of China

Flow Construction

Construction Cost 


\section{Appendix}

Table A1. HoQ matrix between industrial BIM capability and TQC in CEM.

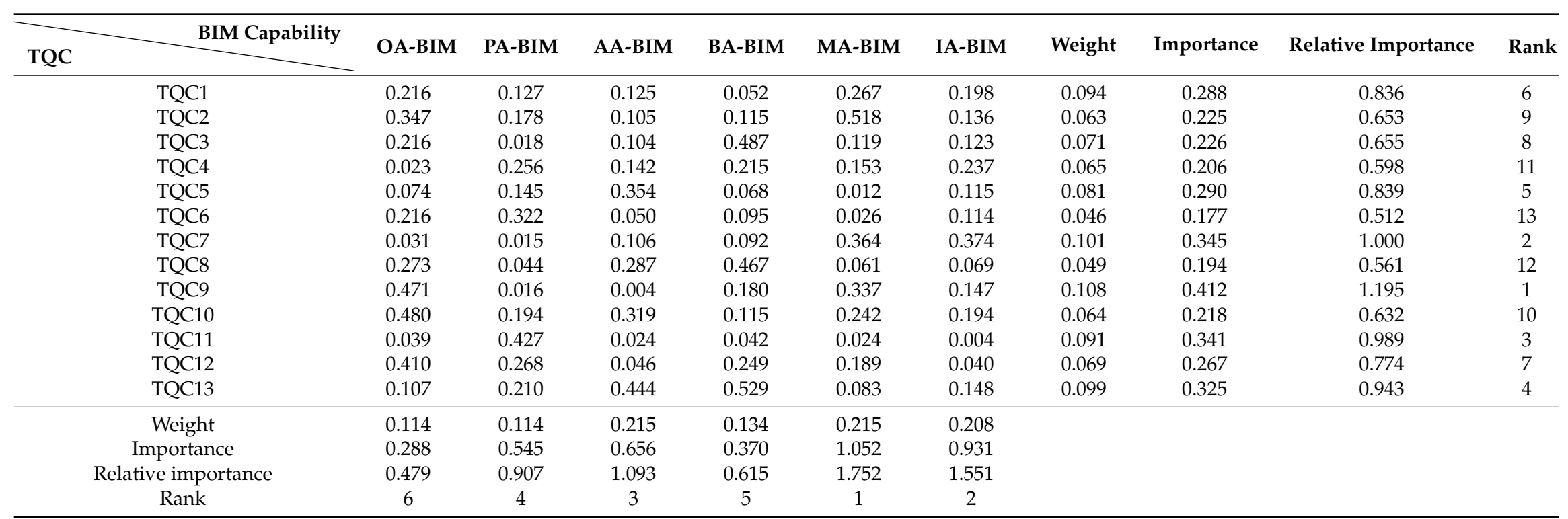


Table A2. HoQ matrix of curriculum points of CC and TQC.

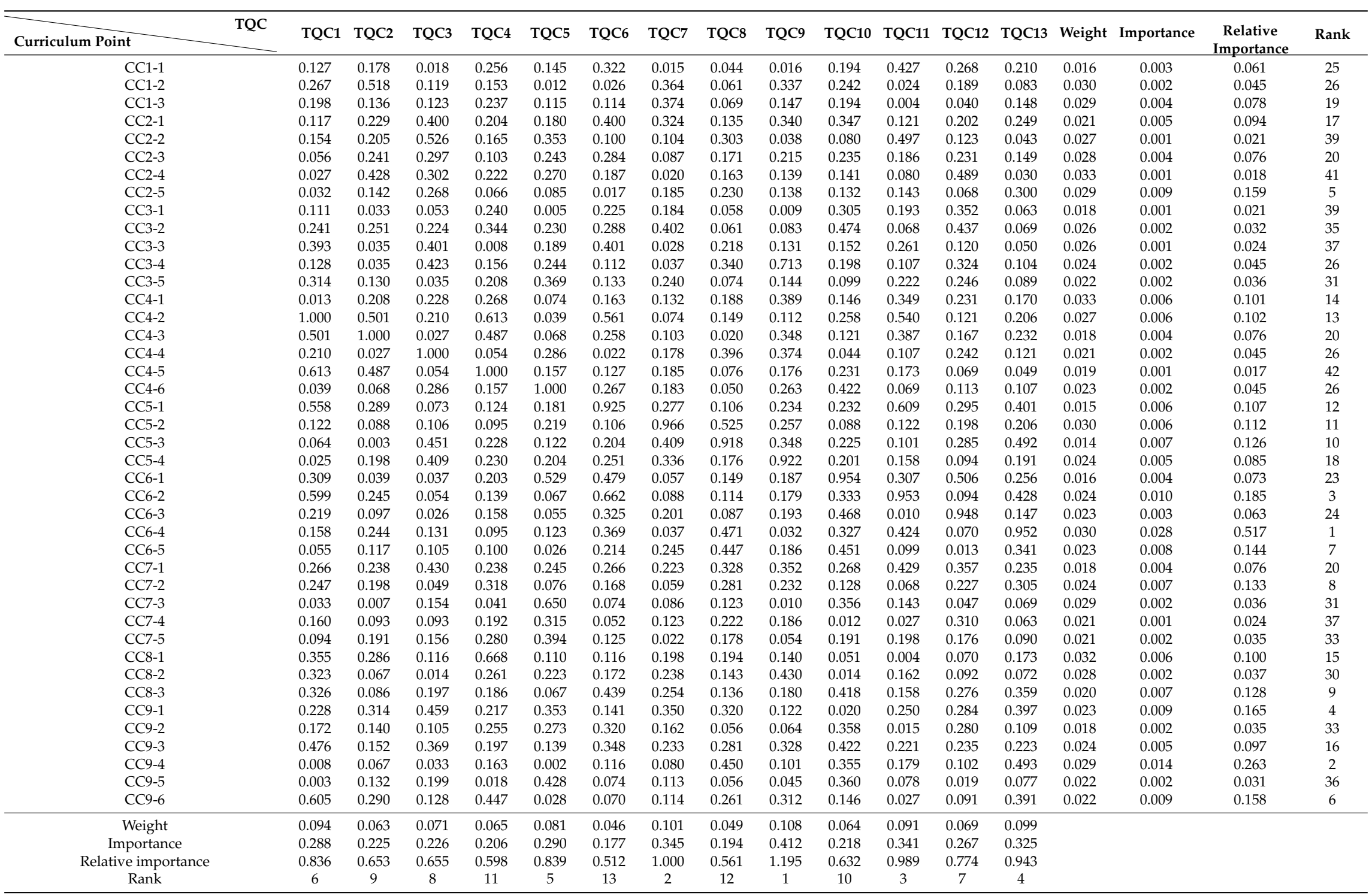


Table A3. HoQ matrix of curriculum points of CC and TQM.

\begin{tabular}{|c|c|c|c|c|c|c|c|c|c|c|c|c|c|c|}
\hline Curriculum Point & $\mathrm{TQC}$ & TQM1-1 & TQM1-2 & TQM1-3 & TQM2-1 & TQM2-2 & TQM2-3 & TQM2-4 & TQM3-1 & TQM3-2 & TQM4-1 & TQM4-2 & TQM4-3 & TQM4-4 \\
\hline CC1-1 & & 0.074 & 0.220 & 0.189 & 0.110 & 0.003 & 0.101 & 0.000 & 0.087 & 0.043 & 0.155 & 0.017 & 0.028 & 0.170 \\
\hline CC1-2 & & 0.357 & 0.031 & 0.171 & 0.216 & 0.095 & 0.034 & 0.000 & 0.162 & 0.403 & 0.246 & 0.533 & 0.301 & 0.192 \\
\hline CC1-3 & & 0.209 & 0.125 & 0.047 & 0.222 & 0.037 & 0.089 & 0.248 & 0.081 & 0.256 & 0.241 & 0.292 & 0.118 & 0.458 \\
\hline CC2-1 & & 0.012 & 0.338 & 0.194 & 0.179 & 0.093 & 0.165 & 0.144 & 0.066 & 0.255 & 0.056 & 0.240 & 0.109 & 0.108 \\
\hline CC2-2 & & 0.399 & 0.384 & 0.332 & 0.068 & 0.043 & 0.443 & 0.025 & 0.031 & 0.487 & 0.266 & 0.439 & 0.113 & 0.651 \\
\hline CC2-3 & & 0.017 & 0.341 & 0.159 & 0.383 & 0.476 & 0.163 & 0.413 & 0.457 & 0.101 & 0.123 & 0.192 & 0.303 & 0.015 \\
\hline CC2-4 & & 0.190 & 0.204 & 0.513 & 0.146 & 0.140 & 0.096 & 0.119 & 0.276 & 0.079 & 0.207 & 0.107 & 0.399 & 0.448 \\
\hline CC2-5 & & 0.088 & 0.317 & 0.040 & 0.110 & 0.560 & 0.074 & 0.274 & 0.504 & 0.177 & 0.145 & 0.130 & 0.026 & 0.237 \\
\hline CC3-1 & & 0.084 & 0.262 & 0.403 & 0.038 & 0.395 & 0.180 & 0.226 & 0.108 & 0.024 & 0.036 & 0.237 & 0.521 & 0.243 \\
\hline CC3-2 & & 0.658 & 0.264 & 0.102 & 0.318 & 0.199 & 0.278 & 0.280 & 0.462 & 0.460 & 0.217 & 0.000 & 0.075 & 0.115 \\
\hline CC $3-3$ & & 0.215 & 0.021 & 0.208 & 0.002 & 0.242 & 0.032 & 0.281 & 0.046 & 0.191 & 0.061 & 0.518 & 0.406 & 0.074 \\
\hline CC3-4 & & 0.034 & 0.025 & 0.143 & 0.319 & 0.494 & 0.122 & 0.163 & 0.373 & 0.429 & 0.238 & 0.306 & 0.126 & 0.091 \\
\hline CC3-5 & & 0.191 & 0.404 & 0.311 & 0.034 & 0.216 & 0.430 & 0.172 & 0.129 & 0.320 & 0.000 & 0.249 & 0.100 & 0.005 \\
\hline CC4-1 & & 0.252 & 0.421 & 0.064 & 0.226 & 0.446 & 0.119 & 0.187 & 0.088 & 0.392 & 0.483 & 0.008 & 0.061 & 0.281 \\
\hline CC4-2 & & 0.211 & 0.233 & 0.258 & 0.212 & 0.116 & 0.242 & 0.162 & 0.011 & 0.036 & 0.052 & 0.163 & 0.298 & 0.152 \\
\hline CC4-3 & & 0.141 & 0.218 & 0.094 & 0.091 & 0.052 & 0.097 & 0.000 & 0.019 & 0.180 & 0.242 & 0.118 & 0.071 & 0.215 \\
\hline CC4-4 & & 0.274 & 0.049 & 0.085 & 0.335 & 0.062 & 0.251 & 0.107 & 0.075 & 0.308 & 0.277 & 0.335 & 0.322 & 0.309 \\
\hline CC4-5 & & 0.124 & 0.380 & 0.105 & 0.027 & 0.120 & 0.413 & 0.192 & 0.212 & 0.134 & 0.186 & 0.007 & 0.371 & 0.151 \\
\hline CC4-6 & & 0.124 & 0.012 & 0.109 & 0.307 & 0.283 & 0.528 & 0.225 & 0.373 & 0.009 & 0.125 & 0.144 & 0.131 & 0.175 \\
\hline CC5-1 & & 0.153 & 0.170 & 0.280 & 0.355 & 0.164 & 0.327 & 0.229 & 0.082 & 0.086 & 0.278 & 0.265 & 0.115 & 0.215 \\
\hline CC5-2 & & 0.286 & 0.159 & 0.293 & 0.554 & 0.280 & 0.164 & 0.042 & 0.625 & 0.103 & 0.201 & 0.309 & 0.169 & 0.116 \\
\hline CC5-3 & & 0.325 & 0.491 & 0.071 & 0.192 & 0.185 & 0.184 & 0.057 & 0.217 & 0.191 & 0.056 & 0.259 & 0.166 & 0.038 \\
\hline CC5-4 & & 0.295 & 0.214 & 0.115 & 0.557 & 0.387 & 0.145 & 0.089 & 0.354 & 0.074 & 0.430 & 0.022 & 0.203 & 0.191 \\
\hline CC6-1 & & 0.279 & 0.123 & 0.190 & 0.139 & 0.162 & 0.386 & 0.387 & 0.348 & 0.140 & 0.375 & 0.066 & 0.454 & 0.298 \\
\hline CC6-2 & & 0.059 & 0.260 & 0.155 & 0.201 & 0.109 & 0.113 & 0.133 & 0.084 & 0.048 & 0.129 & 0.184 & 0.283 & 0.008 \\
\hline СС6-3 & & 0.360 & 0.307 & 0.382 & 0.202 & 0.544 & 0.125 & 0.523 & 0.091 & 0.103 & 0.423 & 0.190 & 0.314 & 0.243 \\
\hline CC6-4 & & 0.128 & 0.364 & 0.049 & 0.081 & 0.352 & 0.233 & 0.249 & 0.062 & 0.049 & 0.322 & 0.034 & 0.131 & 0.073 \\
\hline CC6-5 & & 0.081 & 0.220 & 0.138 & 0.281 & 0.068 & 0.081 & 0.047 & 0.241 & 0.138 & 0.322 & 0.151 & 0.345 & 0.089 \\
\hline CC7-1 & & 0.383 & 0.017 & 0.002 & 0.185 & 0.078 & 0.211 & 0.183 & 0.134 & 0.113 & 0.177 & 0.423 & 0.553 & 0.190 \\
\hline CC7-2 & & 0.482 & 0.118 & 0.193 & 0.017 & 0.086 & 0.284 & 0.218 & 0.100 & 0.081 & 0.026 & 0.132 & 0.118 & 0.161 \\
\hline CC7-3 & & 0.177 & 0.023 & 0.097 & 0.015 & 0.073 & 0.422 & 0.249 & 0.179 & 0.325 & 0.024 & 0.007 & 0.085 & 0.545 \\
\hline CC7-4 & & 0.371 & 0.150 & 0.198 & 0.106 & 0.396 & 0.284 & 0.283 & 0.127 & 0.513 & 0.034 & 0.173 & 0.108 & 0.250 \\
\hline CC7-5 & & 0.228 & 0.687 & 0.125 & 0.362 & 0.055 & 0.113 & 0.273 & 0.190 & 0.050 & 0.159 & 0.300 & 0.122 & 0.337 \\
\hline CC $8-1$ & & 0.109 & 0.458 & 0.332 & 0.285 & 0.075 & 0.144 & 0.079 & 0.111 & 0.099 & 0.038 & 0.277 & 0.147 & 0.090 \\
\hline CC $8-2$ & & 0.240 & 0.125 & 0.227 & 0.545 & 0.203 & 0.024 & 0.324 & 0.348 & 0.078 & 0.118 & 0.358 & 0.015 & 0.047 \\
\hline CC $8-3$ & & 0.129 & 0.377 & 0.174 & 0.319 & 0.365 & 0.101 & 0.101 & 0.582 & 0.103 & 0.049 & 0.106 & 0.189 & 0.636 \\
\hline CC9-1 & & 0.198 & 0.114 & 0.082 & 0.168 & 0.195 & 0.472 & 0.167 & 0.140 & 0.490 & 0.135 & 0.120 & 0.021 & 0.207 \\
\hline CC9-2 & & 0.042 & 0.216 & 0.005 & 0.007 & 0.050 & 0.209 & 0.063 & 0.305 & 0.120 & 0.061 & 0.071 & 0.025 & 0.457 \\
\hline CC9-3 & & 0.051 & 0.042 & 0.193 & 0.159 & 0.465 & 0.122 & 0.209 & 0.272 & 0.121 & 0.507 & 0.068 & 0.204 & 0.055 \\
\hline CC9-4 & & 0.259 & 0.279 & 0.219 & 0.140 & 0.336 & 0.348 & 0.325 & 0.180 & 0.436 & 0.032 & 0.359 & 0.197 & 0.122 \\
\hline CC9-5 & & 0.137 & 0.073 & 0.374 & 0.223 & 0.098 & 0.151 & 0.219 & 0.049 & 0.074 & 0.159 & 0.021 & 0.252 & 0.195 \\
\hline CC9-6 & & 0.231 & 0.267 & 0.466 & 0.040 & 0.288 & 0.045 & 0.260 & 0.084 & 0.096 & 0.224 & 0.078 & 0.161 & 0.010 \\
\hline Weight & & 0.059 & 0.049 & 0.038 & 0.038 & 0.030 & 0.045 & 0.052 & 0.044 & 0.039 & 0.055 & 0.037 & 0.040 & 0.031 \\
\hline Importance & & 0.196 & 0.136 & 0.134 & 0.124 & 0.113 & 0.173 & 0.207 & 0.155 & 0.137 & 0.222 & 0.134 & 0.144 & 0.106 \\
\hline Relative importance & & 1.356 & 0.944 & 0.929 & 0.861 & 0.784 & 1.196 & 1.437 & 1.076 & 0.950 & 1.538 & 0.927 & 1.000 & 0.736 \\
\hline Rank & & 4 & 16 & 17 & 19 & 21 & 7 & 3 & 10 & 15 & 1 & 18 & 12 & 23 \\
\hline
\end{tabular}


Table A4. HoQ matrix of curriculum points of construction cost and TQM.

\begin{tabular}{|c|c|c|c|c|c|c|c|c|c|c|c|c|c|c|c|}
\hline Curriculum Point & $\mathrm{TQM}$ & TQM4-5 & TQM4-6 & TQM5-1 & TQM5-2 & TQM5-3 & TQM5-4 & TQM6-1 & TQM6-2 & TQM6-3 & TQM6-4 & Weight & Importance & Relative Importance & Rank \\
\hline CC1-1 & & 0.133 & 0.117 & 0.150 & 0.373 & 0.243 & 0.178 & 0.307 & 0.012 & 0.016 & 0.107 & 0.016 & 0.002 & 0.031 & 29 \\
\hline CC1-2 & & 0.014 & 0.055 & 0.090 & 0.470 & 0.225 & 0.237 & 0.220 & 0.406 & 0.397 & 0.550 & 0.030 & 0.016 & 0.299 & 2 \\
\hline CC1-3 & & 0.085 & 0.144 & 0.234 & 0.269 & 0.136 & 0.106 & 0.096 & 0.018 & 0.371 & 0.166 & 0.029 & 0.005 & 0.087 & 18 \\
\hline CC2-1 & & 0.258 & 0.418 & 0.071 & 0.182 & 0.014 & 0.519 & 0.267 & 0.008 & 0.052 & 0.223 & 0.021 & 0.005 & 0.084 & 19 \\
\hline CC2-2 & & 0.256 & 0.004 & 0.037 & 0.246 & 0.340 & 0.150 & 0.488 & 0.019 & 0.222 & 0.207 & 0.027 & 0.006 & 0.100 & 14 \\
\hline CC2-3 & & 0.061 & 0.061 & 0.367 & 0.289 & 0.322 & 0.006 & 0.330 & 0.268 & 0.039 & 0.011 & 0.028 & 0.000 & 0.006 & 41 \\
\hline CC2-4 & & 0.013 & 0.124 & 0.258 & 0.406 & 0.048 & 0.231 & 0.192 & 0.016 & 0.019 & 0.021 & 0.033 & 0.001 & 0.013 & 38 \\
\hline CC2-5 & & 0.179 & 0.111 & 0.069 & 0.325 & 0.291 & 0.142 & 0.403 & 0.429 & 0.224 & 0.270 & 0.029 & 0.008 & 0.143 & 9 \\
\hline CC3-1 & & 0.150 & 0.059 & 0.311 & 0.218 & 0.068 & 0.144 & 0.304 & 0.434 & 0.102 & 0.156 & 0.018 & 0.003 & 0.051 & 25 \\
\hline CC3-2 & & 0.347 & 0.110 & 0.235 & 0.273 & 0.631 & 0.184 & 0.161 & 0.104 & 0.024 & 0.452 & 0.026 & 0.012 & 0.213 & 3 \\
\hline CC3-4 & & 0.083 & 0.041 & 0.533 & 0.017 & 0.183 & 0.092 & 0.031 & 0.317 & 0.054 & 0.030 & 0.024 & 0.001 & 0.013 & 37 \\
\hline CC3-5 & & 0.375 & 0.188 & 0.226 & 0.063 & 0.295 & 0.061 & 0.298 & 0.231 & 0.289 & 0.452 & 0.022 & 0.010 & 0.184 & 5 \\
\hline CC4-1 & & 0.163 & 0.045 & 0.438 & 0.254 & 0.337 & 0.080 & 0.252 & 0.044 & 0.182 & 0.193 & 0.033 & 0.006 & 0.115 & 12 \\
\hline CC4-2 & & 0.111 & 0.504 & 0.019 & 0.045 & 0.403 & 0.328 & 0.374 & 0.001 & 0.249 & 0.009 & 0.027 & 0.000 & 0.005 & 42 \\
\hline CC4-3 & & 0.217 & 0.203 & 0.042 & 0.581 & 0.057 & 0.138 & 0.180 & 0.104 & 0.411 & 0.216 & 0.018 & 0.004 & 0.071 & 22 \\
\hline CC4-4 & & 0.211 & 0.346 & 0.182 & 0.248 & 0.011 & 0.716 & 0.041 & 0.260 & 0.086 & 0.023 & 0.021 & 0.000 & 0.009 & 39 \\
\hline CC4-5 & & 0.259 & 0.479 & 0.009 & 0.254 & 0.143 & 0.336 & 0.148 & 0.084 & 0.453 & 0.157 & 0.019 & 0.003 & 0.054 & 24 \\
\hline CC4-6 & & 0.060 & 0.077 & 0.344 & 0.218 & 0.328 & 0.123 & 0.037 & 0.018 & 0.334 & 0.052 & 0.023 & 0.001 & 0.022 & 32 \\
\hline CC5-1 & & 0.116 & 0.017 & 0.203 & 0.082 & 0.459 & 0.228 & 0.066 & 0.357 & 0.047 & 0.295 & 0.015 & 0.004 & 0.079 & 20 \\
\hline CC5-2 & & 0.229 & 0.549 & 0.044 & 0.165 & 0.458 & 0.091 & 0.048 & 0.171 & 0.221 & 0.031 & 0.030 & 0.001 & 0.017 & 34 \\
\hline CC5-3 & & 0.010 & 0.355 & 0.616 & 0.142 & 0.211 & 0.244 & 0.198 & 0.229 & 0.097 & 0.344 & 0.014 & 0.005 & 0.088 & 17 \\
\hline CC5-4 & & 0.036 & 0.072 & 0.348 & 0.054 & 0.212 & 0.052 & 0.102 & 0.138 & 0.134 & 0.207 & 0.024 & 0.005 & 0.092 & 16 \\
\hline CC6-2 & & 0.101 & 0.334 & 0.078 & 0.227 & 0.419 & 0.125 & 0.563 & 0.015 & 0.214 & 0.058 & 0.024 & 0.001 & 0.025 & 30 \\
\hline CC6-3 & & 0.348 & 0.136 & 0.012 & 0.260 & 0.424 & 0.190 & 0.101 & 0.291 & 0.143 & 0.491 & 0.023 & 0.012 & 0.209 & 4 \\
\hline СС6-4 & & 0.441 & 0.270 & 0.394 & 0.408 & 0.133 & 0.457 & 0.336 & 0.023 & 0.032 & 0.031 & 0.030 & 0.001 & 0.017 & 35 \\
\hline CC6-5 & & 0.177 & 0.077 & 0.201 & 0.428 & 0.091 & 0.101 & 0.055 & 0.104 & 0.061 & 0.423 & 0.023 & 0.010 & 0.179 & 7 \\
\hline CC7-1 & & 0.451 & 0.423 & 0.336 & 0.226 & 0.006 & 0.087 & 0.000 & 0.003 & 0.101 & 0.073 & 0.018 & 0.001 & 0.024 & 31 \\
\hline CC7-2 & & 0.302 & 0.416 & 0.206 & 0.203 & 0.297 & 0.160 & 0.251 & 0.012 & 0.040 & 0.262 & 0.024 & 0.006 & 0.114 & 13 \\
\hline CC7-3 & & 0.040 & 0.233 & 0.171 & 0.155 & 0.106 & 0.002 & 0.086 & 0.266 & 0.037 & 0.070 & 0.029 & 0.002 & 0.037 & 27 \\
\hline CC7-4 & & 0.140 & 0.182 & 0.482 & 0.063 & 0.221 & 0.235 & 0.245 & 0.288 & 0.534 & 0.050 & 0.021 & 0.001 & 0.019 & 33 \\
\hline CC7-5 & & 0.239 & 0.054 & 0.066 & 0.213 & 0.251 & 0.090 & 0.220 & 0.025 & 0.071 & 0.186 & 0.021 & 0.004 & 0.073 & 21 \\
\hline CC8-1 & & 0.081 & 0.212 & 0.081 & 0.217 & 0.130 & 0.004 & 0.091 & 0.056 & 0.353 & 0.224 & 0.032 & 0.007 & 0.131 & 10 \\
\hline CC8-2 & & 0.160 & 0.528 & 0.226 & 0.047 & 0.052 & 0.365 & 0.281 & 0.067 & 0.048 & 0.012 & 0.028 & 0.000 & 0.006 & 40 \\
\hline CC8-3 & & 0.141 & 0.023 & 0.018 & 0.363 & 0.336 & 0.120 & 0.350 & 0.304 & 0.321 & 0.116 & 0.020 & 0.002 & 0.041 & 26 \\
\hline CC9-1 & & 0.200 & 0.480 & 0.024 & 0.235 & 0.281 & 0.572 & 0.032 & 0.323 & 0.007 & 0.078 & 0.023 & 0.002 & 0.033 & 28 \\
\hline CC9-2 & & 0.254 & 0.042 & 0.095 & 0.085 & 0.071 & 0.118 & 0.398 & 0.477 & 0.313 & 0.041 & 0.018 & 0.001 & 0.013 & 36 \\
\hline CC9-3 & & 0.063 & 0.158 & 0.152 & 0.015 & 0.049 & 0.183 & 0.151 & 0.149 & 0.095 & 0.397 & 0.024 & 0.010 & 0.173 & 8 \\
\hline CC $9-4$ & & 0.090 & 0.041 & 0.311 & 0.494 & 0.365 & 0.139 & 0.488 & 0.142 & 0.197 & 0.667 & 0.029 & 0.020 & 0.356 & 1 \\
\hline CC9-5 & & 0.094 & 0.105 & 0.105 & 0.145 & 0.178 & 0.259 & 0.032 & 0.181 & 0.163 & 0.229 & 0.022 & 0.005 & 0.092 & 15 \\
\hline CC9-6 & & 0.216 & 0.122 & 0.592 & 0.182 & 0.111 & 0.171 & 0.566 & 0.276 & 0.278 & 0.171 & 0.022 & 0.004 & 0.069 & 23 \\
\hline Weight & & 0.063 & 0.051 & 0.040 & 0.036 & 0.045 & 0.046 & 0.037 & 0.035 & 0.042 & 0.047 & & & & \\
\hline Importance & & 0.212 & 0.156 & 0.143 & 0.119 & 0.173 & 0.174 & 0.112 & 0.139 & 0.152 & 0.160 & & & & \\
\hline Relative importance & & 1.468 & 1.081 & 0.988 & 0.821 & 1.199 & 1.208 & 0.775 & 0.961 & 1.055 & 1.106 & & & & \\
\hline Rank & & 2 & 9 & 13 & 20 & 6 & 5 & 22 & 14 & 11 & 8 & & & & \\
\hline
\end{tabular}


Table A5. HoQ matrix of curriculum points of FCand TQC.

\begin{tabular}{|c|c|c|c|c|c|c|c|c|c|c|c|c|c|c|c|c|c|c|}
\hline Curriculum Point & TQC & TQC1 & TQC2 & TQC3 & TQC4 & TQC5 & TQC6 & TQC7 & TQC8 & TQC9 & TQC10 & TQC11 & TQC12 & TQC13 & Weight & Importance & $\begin{array}{c}\text { Relative } \\
\text { Importance }\end{array}$ & Rank \\
\hline FC1-1 & & 0.181 & 0.258 & 0.076 & 0.145 & 0.043 & 0.033 & 0.297 & 0.147 & 0.290 & 0.154 & 0.111 & 0.075 & 0.033 & 0.048 & 0.116 & 0.969 & 14 \\
\hline FC1-2 & & 0.395 & 0.121 & 0.114 & 0.260 & 0.124 & 0.533 & 0.073 & 0.427 & 0.041 & 0.233 & 0.279 & 0.452 & 0.137 & 0.028 & 0.072 & 0.597 & 24 \\
\hline FC1-3 & & 0.060 & 0.083 & 0.240 & 0.101 & 0.312 & 0.039 & 0.137 & 0.356 & 0.010 & 0.049 & 0.261 & 0.074 & 0.395 & 0.041 & 0.105 & 0.879 & 19 \\
\hline FC1-4 & & 0.511 & 0.193 & 0.203 & 0.156 & 0.006 & 0.282 & 0.259 & 0.329 & 0.431 & 0.041 & 0.469 & 0.036 & 0.118 & 0.039 & 0.094 & 0.782 & 22 \\
\hline FC1-5 & & 0.294 & 0.127 & 0.066 & 0.059 & 0.122 & 0.102 & 0.370 & 0.104 & 0.187 & 0.078 & 0.049 & 0.266 & 0.052 & 0.075 & 0.155 & 1.294 & 2 \\
\hline FC2-1 & & 0.082 & 0.138 & 0.155 & 0.067 & 0.034 & 0.155 & 0.334 & 0.065 & 0.108 & 0.142 & 0.118 & 0.271 & 0.014 & 0.035 & 0.114 & 0.948 & 16 \\
\hline FC2-2 & & 0.311 & 0.094 & 0.132 & 0.476 & 0.069 & 0.184 & 0.057 & 0.360 & 0.132 & 0.039 & 0.005 & 0.150 & 0.165 & 0.042 & 0.129 & 1.073 & 10 \\
\hline FC2-3 & & 0.262 & 0.359 & 0.063 & 0.029 & 0.015 & 0.151 & 0.480 & 0.164 & 0.055 & 0.094 & 0.138 & 0.105 & 0.039 & 0.043 & 0.144 & 1.201 & 6 \\
\hline FC3-1 & & 0.052 & 0.012 & 0.251 & 0.145 & 0.255 & 0.206 & 0.449 & 0.363 & 0.016 & 0.443 & 0.131 & 0.396 & 0.311 & 0.053 & 0.184 & 1.532 & 1 \\
\hline FC3-2 & & 0.057 & 0.194 & 0.261 & 0.038 & 0.019 & 0.200 & 0.164 & 0.015 & 0.016 & 0.008 & 0.191 & 0.050 & 0.298 & 0.043 & 0.149 & 1.242 & 3 \\
\hline FC3-3 & & 0.487 & 0.303 & 0.398 & 0.478 & 0.015 & 0.048 & 0.153 & 0.075 & 0.112 & 0.339 & 0.394 & 0.061 & 0.154 & 0.036 & 0.147 & 1.228 & 4 \\
\hline FC3-4 & & 0.103 & 0.186 & 0.519 & 0.049 & 0.108 & 0.194 & 0.305 & 0.003 & 0.315 & 0.227 & 0.091 & 0.033 & 0.176 & 0.028 & 0.113 & 0.940 & 17 \\
\hline FC3-5 & & 0.188 & 0.150 & 0.194 & 0.264 & 0.489 & 0.176 & 0.496 & 0.019 & 0.357 & 0.026 & 0.229 & 0.131 & 0.243 & 0.035 & 0.120 & 1.000 & 13 \\
\hline FC3-6 & & 0.041 & 0.426 & 0.147 & 0.286 & 0.097 & 0.026 & 0.390 & 0.184 & 0.037 & 0.004 & 0.082 & 0.357 & 0.150 & 0.027 & 0.120 & 1.001 & 12 \\
\hline FC4-1 & & 0.070 & 0.042 & 0.456 & 0.310 & 0.275 & 0.095 & 0.316 & 0.016 & 0.529 & 0.119 & 0.309 & 0.268 & 0.228 & 0.040 & 0.139 & 1.159 & 7 \\
\hline FC4-2 & & 0.165 & 0.070 & 0.024 & 0.211 & 0.094 & 0.013 & 0.461 & 0.393 & 0.407 & 0.103 & 0.014 & 0.007 & 0.410 & 0.031 & 0.097 & 0.807 & 20 \\
\hline FC4-3 & & 0.379 & 0.021 & 0.047 & 0.513 & 0.553 & 0.078 & 0.363 & 0.231 & 0.418 & 0.183 & 0.028 & 0.141 & 0.287 & 0.038 & 0.147 & 1.221 & 5 \\
\hline FC4-4 & & 0.037 & 0.234 & 0.275 & 0.297 & 0.267 & 0.059 & 0.237 & 0.036 & 0.126 & 0.409 & 0.414 & 0.287 & 0.267 & 0.022 & 0.070 & 0.583 & 25 \\
\hline FC4-5 & & 0.250 & 0.039 & 0.643 & 0.236 & 0.187 & 0.039 & 0.137 & 0.212 & 0.098 & 0.093 & 0.048 & 0.074 & 0.287 & 0.028 & 0.095 & 0.792 & 21 \\
\hline FC4-6 & & 0.469 & 0.034 & 0.186 & 0.364 & 0.005 & 0.242 & 0.479 & 0.286 & 0.161 & 0.235 & 0.407 & 0.377 & 0.132 & 0.033 & 0.129 & 1.075 & 9 \\
\hline FC5-1 & & 0.186 & 0.334 & 0.418 & 0.349 & 0.140 & 0.310 & 0.259 & 0.226 & 0.385 & 0.276 & 0.063 & 0.209 & 0.268 & 0.036 & 0.093 & 0.778 & 23 \\
\hline FC5-2 & & 0.157 & 0.255 & 0.489 & 0.265 & 0.476 & 0.187 & 0.036 & 0.244 & 0.037 & 0.124 & 0.483 & 0.016 & 0.016 & 0.043 & 0.116 & 0.963 & 15 \\
\hline FC5-3 & & 0.062 & 0.188 & 0.384 & 0.012 & 0.182 & 0.218 & 0.011 & 0.187 & 0.229 & 0.176 & 0.198 & 0.316 & 0.139 & 0.055 & 0.124 & 1.031 & 11 \\
\hline FC5-4 & & 0.014 & 0.507 & 0.170 & 0.233 & 0.280 & 0.191 & 0.059 & 0.147 & 0.087 & 0.162 & 0.052 & 0.587 & 0.063 & 0.055 & 0.132 & 1.098 & 8 \\
\hline FC5-5 & & 0.018 & 0.118 & 0.272 & 0.071 & 0.059 & 0.021 & 0.291 & 0.166 & 0.200 & 0.031 & 0.288 & 0.078 & 0.167 & 0.045 & 0.110 & 0.919 & 18 \\
\hline Weight & & 0.094 & 0.063 & 0.071 & 0.065 & 0.081 & 0.046 & 0.101 & 0.049 & 0.108 & 0.064 & 0.091 & 0.069 & 0.099 & & & & \\
\hline Importance & & 0.288 & 0.225 & 0.226 & 0.206 & 0.290 & 0.177 & 0.345 & 0.194 & 0.412 & 0.218 & 0.341 & 0.267 & 0.325 & & & & \\
\hline Relative importance & & 0.836 & 0.653 & 0.655 & 0.598 & 0.839 & 0.512 & 1.000 & 0.561 & 1.195 & 0.632 & 0.989 & 0.774 & 0.943 & & & & \\
\hline Rank & & 6 & 9 & 8 & 11 & 5 & 13 & 2 & 12 & 1 & 10 & 3 & 7 & 4 & & & & \\
\hline
\end{tabular}


Table A6. HoQ matrix of curriculum points of FC and TQM.

\begin{tabular}{|c|c|c|c|c|c|c|c|c|c|c|c|c|c|c|}
\hline Curriculum Point & TQM & TQM1-1 & TQM1-2 & TQM1-3 & TQM2-1 & TQM2-2 & TQM2-3 & TQM2-4 & TQM3-1 & TQM3-2 & TQM4-1 & TQM4-2 & TQM4-3 & TQM4-4 \\
\hline FC1-1 & & 0.276 & 0.128 & 0.385 & 0.092 & 0.073 & 0.930 & 0.014 & 0.021 & 0.346 & 0.296 & 0.381 & 0.020 & 0.272 \\
\hline FC1-2 & & 0.195 & 0.228 & 0.058 & 0.453 & 0.149 & 0.112 & 0.911 & 0.176 & 0.410 & 0.045 & 0.107 & 0.471 & 0.292 \\
\hline FC1-3 & & 0.566 & 0.367 & 0.095 & 0.014 & 0.036 & 0.061 & 0.127 & 0.962 & 0.115 & 0.385 & 0.299 & 0.101 & 0.093 \\
\hline FC1-4 & & 0.173 & 0.417 & 0.223 & 0.409 & 0.027 & 0.133 & 0.313 & 0.055 & 0.942 & 0.187 & 0.056 & 0.350 & 0.142 \\
\hline FC1-5 & & 0.316 & 0.005 & 0.193 & 0.081 & 0.207 & 0.280 & 0.029 & 0.349 & 0.279 & 0.974 & 0.016 & 0.263 & 0.309 \\
\hline FC2-1 & & 0.032 & 0.360 & 0.043 & 0.006 & 0.082 & 0.536 & 0.060 & 0.307 & 0.178 & 0.052 & 1.000 & 0.300 & 0.306 \\
\hline FC2-2 & & 0.177 & 0.003 & 0.013 & 0.109 & 0.302 & 0.122 & 0.296 & 0.090 & 0.333 & 0.208 & 0.300 & 1.000 & 0.086 \\
\hline FC2-3 & & 0.073 & 0.146 & 0.324 & 0.263 & 0.013 & 0.369 & 0.430 & 0.078 & 0.015 & 0.345 & 0.306 & 0.086 & 1.000 \\
\hline FC3-1 & & 0.361 & 0.291 & 0.394 & 0.142 & 0.029 & 0.368 & 0.012 & 0.478 & 0.353 & 0.140 & 0.368 & 0.227 & 0.195 \\
\hline FC3-2 & & 0.268 & 0.328 & 0.101 & 0.238 & 0.309 & 0.204 & 0.260 & 0.049 & 0.029 & 0.347 & 0.219 & 0.505 & 0.027 \\
\hline FC3-3 & & 0.097 & 0.148 & 0.058 & 0.354 & 0.149 & 0.082 & 0.021 & 0.328 & 0.479 & 0.321 & 0.329 & 0.409 & 0.101 \\
\hline FC3-4 & & 0.335 & 0.029 & 0.160 & 0.103 & 0.115 & 0.163 & 0.078 & 0.428 & 0.089 & 0.488 & 0.104 & 0.218 & 0.428 \\
\hline FC3-5 & & 0.000 & 0.092 & 0.173 & 0.072 & 0.380 & 0.289 & 0.026 & 0.346 & 0.134 & 0.199 & 0.393 & 0.119 & 0.365 \\
\hline FC3-6 & & 0.194 & 0.203 & 0.353 & 0.496 & 0.516 & 0.246 & 0.179 & 0.035 & 0.257 & 0.353 & 0.002 & 0.203 & 0.195 \\
\hline FC4-1 & & 0.177 & 0.002 & 0.344 & 0.385 & 0.068 & 0.084 & 0.050 & 0.163 & 0.313 & 0.262 & 0.059 & 0.127 & 0.325 \\
\hline FC4-2 & & 0.327 & 0.259 & 0.031 & 0.029 & 0.272 & 0.451 & 0.242 & 0.462 & 0.176 & 0.050 & 0.312 & 0.147 & 0.324 \\
\hline FC4-3 & & 0.423 & 0.141 & 0.274 & 0.171 & 0.007 & 0.199 & 0.054 & 0.414 & 0.072 & 0.083 & 0.155 & 0.403 & 0.346 \\
\hline FC4-4 & & 0.174 & 0.055 & 0.226 & 0.140 & 0.358 & 0.111 & 0.384 & 0.015 & 0.055 & 0.089 & 0.067 & 0.465 & 0.411 \\
\hline FC4-5 & & 0.404 & 0.138 & 0.006 & 0.014 & 0.217 & 0.199 & 0.094 & 0.507 & 0.319 & 0.299 & 0.151 & 0.016 & 0.018 \\
\hline FC4-6 & & 0.264 & 0.089 & 0.027 & 0.014 & 0.074 & 0.449 & 0.002 & 0.336 & 0.440 & 0.012 & 0.599 & 0.410 & 0.288 \\
\hline FC5-1 & & 0.173 & 0.186 & 0.332 & 0.181 & 0.027 & 0.224 & 0.278 & 0.177 & 0.248 & 0.141 & 0.214 & 0.308 & 0.180 \\
\hline FC5-2 & & 0.077 & 0.049 & 0.051 & 0.066 & 0.017 & 0.350 & 0.072 & 0.225 & 0.034 & 0.146 & 0.022 & 0.086 & 0.045 \\
\hline FC5-3 & & 0.297 & 0.018 & 0.263 & 0.153 & 0.265 & 0.032 & 0.159 & 0.316 & 0.037 & 0.270 & 0.325 & 0.331 & 0.118 \\
\hline FC5-4 & & 0.145 & 0.425 & 0.267 & 0.343 & 0.194 & 0.277 & 0.609 & 0.012 & 0.091 & 0.272 & 0.179 & 0.223 & 0.085 \\
\hline FC5-5 & & 0.081 & 0.218 & 0.187 & 0.219 & 0.092 & 0.115 & 0.068 & 0.345 & 0.081 & 0.242 & 0.165 & 0.486 & 0.218 \\
\hline Weight & & 0.038 & 0.058 & 0.037 & 0.046 & 0.029 & 0.053 & 0.031 & 0.046 & 0.040 & 0.066 & 0.041 & 0.049 & 0.051 \\
\hline Importance & & 0.003 & 0.013 & 0.007 & 0.010 & 0.003 & 0.006 & 0.002 & 0.016 & 0.003 & 0.016 & 0.007 & 0.024 & 0.011 \\
\hline Relative importance & & 0.020 & 0.082 & 0.046 & 0.066 & 0.018 & 0.040 & 0.014 & 0.103 & 0.021 & 0.104 & 0.044 & 0.158 & 0.072 \\
\hline Rank & & 20 & 10 & 16 & 13 & 21 & 18 & 23 & 6 & 19 & 5 & 17 & 3 & 11 \\
\hline
\end{tabular}


Table A7. HoQ matrix of curriculum points of FC and TQM.

\begin{tabular}{|c|c|c|c|c|c|c|c|c|c|c|c|c|c|c|}
\hline Curriculum Point & TQM & TQM4-6 & TQM5-1 & TQM5-2 & TQM5-3 & TQM5-4 & TQM6-1 & TQM6-2 & TQM6-3 & TQM6-4 & Weight & Importance & $\begin{array}{c}\text { Relative } \\
\text { Importance }\end{array}$ & Rank \\
\hline FC1-1 & & 0.118 & 0.110 & 0.078 & 0.314 & 0.287 & 0.105 & 0.436 & 0.203 & 0.129 & 0.048 & 0.116 & 0.969 & 14 \\
\hline FC1-2 & & 0.347 & 0.278 & 0.049 & 0.020 & 0.254 & 0.090 & 0.289 & 0.159 & 0.520 & 0.028 & 0.072 & 0.597 & 24 \\
\hline FC1-3 & & 0.064 & 0.229 & 0.367 & 0.327 & 0.090 & 0.149 & 0.373 & 0.391 & 0.063 & 0.041 & 0.105 & 0.879 & 19 \\
\hline FC1-4 & & 0.028 & 0.458 & 0.147 & 0.172 & 0.314 & 0.256 & 0.057 & 0.050 & 0.104 & 0.039 & 0.094 & 0.782 & 22 \\
\hline FC1-5 & & 0.356 & 0.331 & 0.507 & 0.158 & 0.353 & 0.280 & 0.147 & 0.050 & 0.186 & 0.075 & 0.155 & 1.294 & 2 \\
\hline FC2-1 & & 0.219 & 0.329 & 0.104 & 0.393 & 0.002 & 0.059 & 0.312 & 0.155 & 0.067 & 0.035 & 0.114 & 0.948 & 16 \\
\hline FC2-2 & & 0.505 & 0.409 & 0.218 & 0.119 & 0.203 & 0.127 & 0.147 & 0.403 & 0.465 & 0.042 & 0.129 & 1.073 & 10 \\
\hline $\mathrm{FC} 2-3$ & & 0.027 & 0.101 & 0.428 & 0.365 & 0.195 & 0.325 & 0.324 & 0.346 & 0.411 & 0.043 & 0.144 & 1.201 & 6 \\
\hline FC3-1 & & 0.159 & 0.065 & 0.228 & 0.381 & 0.141 & 0.152 & 0.451 & 0.219 & 0.432 & 0.053 & 0.184 & 1.532 & 1 \\
\hline FC3-2 & & 1.000 & 0.468 & 0.154 & 0.007 & 0.316 & 0.349 & 0.057 & 0.102 & 0.546 & 0.043 & 0.149 & 1.242 & 3 \\
\hline FC3-3 & & 0.468 & 1.000 & 0.187 & 0.314 & 0.220 & 0.272 & 0.142 & 0.251 & 0.348 & 0.036 & 0.147 & 1.228 & 4 \\
\hline FC3-4 & & 0.154 & 0.187 & 1.000 & 0.016 & 0.141 & 0.565 & 0.290 & 0.029 & 0.142 & 0.028 & 0.113 & 0.940 & 17 \\
\hline FC3-5 & & 0.007 & 0.314 & 0.016 & 1.000 & 0.402 & 0.402 & 0.300 & 0.632 & 0.243 & 0.035 & 0.120 & 1.000 & 13 \\
\hline FC3-6 & & 0.316 & 0.220 & 0.141 & 0.402 & 1.000 & 0.103 & 0.068 & 0.230 & 0.190 & 0.027 & 0.120 & 1.001 & 12 \\
\hline FC4-1 & & 0.349 & 0.272 & 0.565 & 0.402 & 0.103 & 1.000 & 0.302 & 0.458 & 0.002 & 0.040 & 0.139 & 1.159 & 7 \\
\hline FC4-2 & & 0.057 & 0.142 & 0.290 & 0.300 & 0.068 & 0.302 & 1.000 & 0.404 & 0.206 & 0.031 & 0.097 & 0.807 & 20 \\
\hline FC4-3 & & 0.102 & 0.251 & 0.029 & 0.632 & 0.230 & 0.458 & 0.404 & 1.000 & 0.054 & 0.038 & 0.147 & 1.221 & 5 \\
\hline FC4-4 & & 0.546 & 0.348 & 0.142 & 0.243 & 0.190 & 0.002 & 0.206 & 0.054 & 1.000 & 0.022 & 0.070 & 0.583 & 25 \\
\hline FC4-5 & & 0.064 & 0.428 & 0.653 & 0.368 & 0.208 & 0.240 & 0.145 & 0.277 & 0.151 & 0.028 & 0.095 & 0.792 & 21 \\
\hline FC4-6 & & 0.096 & 0.355 & 0.220 & 0.456 & 0.116 & 0.120 & 0.440 & 0.508 & 0.096 & 0.033 & 0.129 & 1.075 & 9 \\
\hline FC5-1 & & 0.028 & 0.404 & 0.270 & 0.349 & 0.131 & 0.083 & 0.138 & 0.255 & 0.067 & 0.036 & 0.093 & 0.778 & 23 \\
\hline FC5-2 & & 0.049 & 0.253 & 0.016 & 0.475 & 0.084 & 0.028 & 0.106 & 0.188 & 0.388 & 0.043 & 0.116 & 0.963 & 15 \\
\hline FC5-3 & & 0.211 & 0.264 & 0.223 & 0.025 & 0.143 & 0.287 & 0.272 & 0.236 & 0.023 & 0.055 & 0.124 & 1.031 & 11 \\
\hline FC5-4 & & 0.359 & 0.116 & 0.124 & 0.144 & 0.606 & 0.029 & 0.115 & 0.042 & 0.278 & 0.055 & 0.132 & 1.098 & 8 \\
\hline FC5-5 & & 0.551 & 0.322 & 0.258 & 0.260 & 0.455 & 0.191 & 0.503 & 0.060 & 0.535 & 0.045 & 0.110 & 0.919 & 18 \\
\hline Weight & & 0.050 & 0.043 & 0.033 & 0.041 & 0.032 & 0.047 & 0.037 & 0.045 & 0.026 & & & & \\
\hline Importance & & 0.028 & 0.014 & 0.008 & 0.011 & 0.015 & 0.009 & 0.018 & 0.003 & 0.014 & & & & \\
\hline Relative importance & & 0.182 & 0.090 & 0.055 & 0.070 & 0.095 & 0.059 & 0.120 & 0.018 & 0.092 & & & & \\
\hline Rank & & 2 & 9 & 15 & 12 & 7 & 14 & 4 & 21 & 8 & & & & \\
\hline
\end{tabular}


Table A8. The information of industrial individual and faculty in this research.

\begin{tabular}{cclll}
\hline NO. & Work Experience & \multicolumn{1}{c}{ Workplace } & \multicolumn{1}{c}{ Major } & \multicolumn{1}{c}{ Title } \\
\hline 1 & 9 years & Construction Company & BIM consultant & Project Coordinator \\
2 & 10 years & Construction Company & Construction management & Project Manager \\
3 & 15 years & Higher University & Construction management & Associate Professor \\
4 & 12 years & Construction Company & Construction management & Project Manager \\
5 & 11 years & Construction Company & Construction management & Project Coordinator \\
6 & 16 years & Owner & Construction management & Construction Marketing Administrator \\
7 & 18 years & Owner & Construction management & Construction Superintendent \\
8 & 21 years & Higher University & Construction management & Associate Professor \\
9 & 9 years & Construction Company & BIM consultant & Project Coordinator \\
10 & 25 years & Higher University & Construction management & Professor \\
11 & 13 years & Higher University & Construction management & Associate professor \\
12 & 10 years & Owner & BIM consultant & Project Manager \\
13 & 9 years & Construction Company & BIM consultant & Project Coordinator \\
14 & 12 years & Higher University & Construction management & Associate professor \\
15 & 19 years & Higher University & Construction management & Professor \\
16 & 14 years & Owner & Construction management & Project Coordinator \\
17 & 17 years & Higher University & Construction management & Professor \\
\hline
\end{tabular}




\section{References}

1. Ahmad, T.; Thaheem, M.J.; Anwar, A. Developing a green-building design approach by selective use of systems and techniques. Archit. Eng. Des. Manag. 2016, 12, 29-50. [CrossRef]

2. Azhar, S. Building information modeling (BIM): Trends, benefits, risks, and challenges for the aec industry. Am. Soc. Civil Eng. 2011, 11, 241-252. [CrossRef]

3. Cable, V.; Fallon, M.; Higgins, D. Construction 2025; HM Government: London, UK, 2013.

4. Bynum, P.; Issa, R.R.A.; Olbina, S. Building information modeling in support of sustainable design and construction. J. Constr. Eng. Manag. 2013, 139, 24-34. [CrossRef]

5. Adshead, J. Green Buildings and the Law; Spon Press: London, UK; New York, NY, USA, 2011.

6. Bernstein, H.M. Business Valueof BIM for Construction in Major Global Markets Smart Market Report: How Contractors around the World are Driving Innovation with Building Information Model; Dodge Data \& Analytics: Berford, MA, USA, 2014.

7. Lee, N.; Dossick, C.S.; Foley, S.P. Guideline for building information modeling in construction engineering and management education. J. Prof. Issues Eng. Educ. Pract. 2013, 139, 266-274. [CrossRef]

8. Gaver, J.F. The American Council for Construction Education (ACCE) Annual Report 2013-2014; The American Council for Construction Education: San Antonio, TX, USA, 2014.

9. Fridrich, J.; Kubecka, K. BIM-The process of modern civil engineering in higher education. Procedia Soc. Behav. Sci. 2014, 141, 763-767. [CrossRef]

10. Korman, T.M.; Huey-King, L. Industry input for construction engineering and management courses: Development of a building systems coordination exercise for construction engineering and management students. Pract. Period. Struct. Des. Constr. 2014, 19, 68-72. [CrossRef]

11. Wu, W.; Issa, R.R.A. BIM education and recruiting: Survey-based comparative analysis of issues, perceptions, and collaboration opportunities. J. Prof. Issues Eng. Educ. Pract. 2014, 140, 331-361. [CrossRef]

12. Ahn, Y.H.; Cho, C.-S.; Lee, N. Building information modeling: Systematic course development for undergraduate construction students. J. Prof. Issues Eng. Educ. Pract. 2013, 139, 290-300. [CrossRef]

13. Sacks, R.; Pikas, E. Building information modeling education for construction engineering and management. I: Industry requirements, state of the art, and gap analysis. J. Constr. Eng. Manag. 2013, 139, 1-3. [CrossRef]

14. Sacks, R.; Barak, R. Teaching building information modeling as an integral part of freshman year civil engineering education. J. Prof. Issues Eng. Educ. Pract. 2010, 136, 30-38. [CrossRef]

15. Becker, T.; Sanvido, V.; Kufahl, G.; Elston, A.; Woodard, N. Investigation into the relationship of construction engineering and management education with specialty trade contractors. Pract. Period. Struct. Des. Constr. 2014, 19, 20-29. [CrossRef]

16. Asif, M.; Raouf, A. Setting the course for quality assurance in higher education. Qual. Quant. 2013, 47, 2009-2024. [CrossRef]

17. Prabhushankar, G.V.; Shankar, B.L.; Veena, T.R. Curriculum redesign in higher education using qfd: A case study. In Proceedings of the International Conference on Transformations in Engineering Education; Springer: Bangalore, India, 2015; pp. 249-258.

18. Kamvysi, K.; Gotzamani, K.; Andronikidis, A.; Georgiou, A.C. Capturing and prioritizing students' requirements for course design by embedding fuzzy-ahp and linear programming in qfd. Eur. J. Oper. Res. 2014, 237, 1083-1094. [CrossRef]

19. Chiao-Ping, B.; Yu-Ping, L.; Ching-Yaw, C. Enhancement of quality function deployment based on chinkless-teaching concept design courses. Int. J. Organ. Innov. 2013, 5, 63-71.

20. Liu, S.-F.; Lee, Y.-L.; Lin, Y.-Z.; Tseng, C.-F. Applying quality function deployment in industrial design curriculum planning. Int. J. Technol. Des. Educ. 2013, 23, 1147-1160. [CrossRef]

21. Anis, A.; Islam, R. Improving teaching efficiency: An application of qfd and ahp. Int. Workshop Mult. Criteria Decis. Making 2011, 6, 9-35.

22. Bharadwaj, P.N.; Osborne, S.W.; Falcone, T.W. Assuring quality in entrepreneurship training: A quality function deployment (qfd) approach. J. Entrep. Educ. 2010, 13, 107-132.

23. Bas, E. An integrated quality function deployment and capital budgeting methodology for occupational safety and health as a systems thinking approach: The case of the construction industry. Accid. Anal. Prev. 2014, 68, 42-56. [CrossRef] [PubMed] 
24. Violante, M.G.; Vezzetti, E. Implementing a new approach for the design of an e-learning platform in engineering education. Computer Appl. Eng. Educ. 2014, 22, 708-727. [CrossRef]

25. Chen, L.; Ko, W.; Tseng, C. Fuzzy approaches for constructing house of quality in qfd and its applications: A group decision-making method. IEEE Trans. Eng. Manag. 2013, 60, 77-87. [CrossRef]

26. Ren, H. 2013 Guideline for Civil Engineering and Management in China; Steering Committee of Civil Engineering and Management in China: Beijing, China, 2013.

27. Aytac, A.; Deniz, V. Quality function deployment in education: A curriculum review. Qual. Quant. 2005, 39, 507-514. [CrossRef]

28. Abdullah, A.S. Learning assessment of the effectiveness of teaching delivery in manufacturing engineering education. Global J. Engng. Educ. 2003, 7, 227-236.

29. Banal-Estañol, A.; Jofre-Bonet, M.; Lawson, C. The double-edged sword of industry collaboration: Evidence from engineering academics in the uk. Res. Policy 2015, 44, 1160-1175. [CrossRef]

30. Adomßent, M.; Fischer, D.; Godemann, J.; Herzig, C.; Otte, I.; Rieckmann, M.; Timm, J. Emerging areas in research on higher education for sustainable development-management education, sustainable consumption and perspectives from central and eastern europe. J. Clean. Product. 2014, 62, 1-7. [CrossRef]

31. Azhar, S.; Brown, J. BIM for sustainability analyses. Int. J. Constr. Educ. Res. 2009, 5, 276-292. [CrossRef]

32. Hardin, B. BIM and Construction Management : Proven Tools, Methods, and Workflows; Wiley: Indianapolis, IN, USA, 2009.

33. Azhar, S.; Khalfan, M.; Maqsood, T. Building information modeling (BIM): Now and beyond. Australas. J. Constr. Econ. Build. 2012, 12, 15-28. [CrossRef]

34. Becerik-Gerber, B.; Kensek, K. Building information modeling in architecture, engineering, and construction: Emerging research directions and trends. J. Prof. Issues Eng. Educ. Pract. 2010, 136, 139-147. [CrossRef]

35. Kim, K.; Teizer, J. Automatic design and planning of scaffolding systems using building information modeling. Adv. Eng. Inf. 2014, 28, 66-80. [CrossRef]

36. Barlish, K.C.; Traylor, C. Career paths and development: Actions and examples from the heavy civil sector. Pract. Period. Struct. Des. Constr. 2014, 19, 2-7. [CrossRef]

37. National BIM Standard-United States. National BIM Standard-United States Fact Sheet; National Institute of Building Sciences: Washington, DC, USA, 2015; Available online: https:/ /www.nationalbimstandard.org/ (accessed on 23 May 2016).

38. Russell, D.; Cho, Y.K.; Cylwik, E. Learning opportunities and career implications of experience with BIM/vdc. Pract. Period. Struct. Des. Constr. 2014, 19, 111-121. [CrossRef]

39. Wang, L.; Leite, F. Process-oriented approach of teaching building information modeling in construction management. J. Prof. Issues Eng. Educ. Pract. 2014, 140, 9-12. [CrossRef]

40. Forsythe, P.; Jupp, J.; Sawhney, A. Building information modelling in tertiary construction project management education: A programme-wide implementation strategy. J. Educ. Built Environ. 2013, 8, 16-34. [CrossRef]

41. Sacks, R.; Koskela, L.; Dave, B.A.; Owen, R. Interaction of lean and building information modeling in construction. J. Constr. Eng. Manag. 2010, 136, 968-980. [CrossRef]

42. Tribelsky, E.; Sacks, R. Measuring information flow in the detailed design of construction projects. Res. Eng. Des. 2010, 21, 189-206. [CrossRef]

43. Jin-Lee, K. Use of BIM for effective visualization teaching approach in construction education. J. Prof. Issues Eng. Educ. Pract. 2012, 138, 214-223.

44. Succar, B.; Sher, W.; Williams, A. Measuring BIM performance: Five metrics. Archit. Eng. Des. Manag. 2012, 8, 120-142. [CrossRef]

45. Zhang, S.; Ren, H.; Chan, A.P.C. Research on the BIM education reform in construction management discipline i: Based on BIM education of universities analysis in america. Constr. Econ. 2015, 36, 113-116.

46. Xie, M.-J.; Shi, L.; Luo, M. A study of the teaching of integrated sustainable building design based on the BIM platform. J. Central South Univ. For. Technol. (Soc. Sci.) 2012, 6, 146-148.

47. Lei, J.S. BIM workshop construction based on large-scale design competition and practical urban design project. J. Archit. Educ. Inst. High. Learn. 2015, 24, 151-155.

48. Ochs, J.B.; Watkins, T.A.; Boothe, B.W. Creating a truly multidisciplinary entrepreneurial educational environment. J. Eng. Educ. 2001, 90, 577-583. [CrossRef] 
49. Andersson, N. BIM adoption in university teaching programs: The swedish case. In Proceedings of CITA BIM Gathering Conference, Dublin, Ireland, 14-15 November 2013; The Construction IT Alliance: Dublin, Ireland, 2013; pp. 163-168.

50. Altomonte, S.; Rutherford, P.; Wilson, R. Mapping the way forward: Education for sustainability in architecture and urban design. Corp. Soc. Responsib. Environ. Manag. 2014, 21, 143-154. [CrossRef]

51. Archambault, S.G.; Masunaga, J. Curriculum mapping as a strategic planning tool. J. Libr. Admin. 2015, 55, 503-519. [CrossRef]

52. Smith, J.E.; McAuliffe, G.; Rippard, K.S. Counseling students' transformative learning through a study abroad curriculum. Couns. Educ. Superv. 2014, 53, 306-319. [CrossRef]

53. Al-Eraky, M.M. Curriculum navigator: Aspiring towards a comprehensive package for curriculum planning. Medical Teacher 2012, 34, 724-732. [CrossRef] [PubMed]

54. Foxworth, R.; Liu, A.H.; Sokhey, A.E. Incorporating native american history into the curriculum: Descriptive representation or campaign contributions? Soc. Sci. Quart. (Wiley-Blackwell) 2015, 96, 955-969. [CrossRef]

55. Ovbiebo, M.O. Incorporation of environmental education in nigerian colleges of education: An exploration research. Int. J. Multidiscip. Approach Stud. 2015, 2, 10-20.

56. Pakdil, F.; Isin, F.; Genc, H. A quality function deployment application using qualitative and quantitative analysis in after sales services. Total Qual. Manag. Bus. Excell. 2012, 23, 1397-1411. [CrossRef]

57. Sahney, S.; Banwet, D.K.; Karunes, S. An integrated framework for quality in education: Application of quality function deployment, interpretive structural modelling and path analysis. Total Qual. Manag. Bus. Excell. 2006, 17, 265-285. [CrossRef]

58. Lantada, A.D.; Morgado, P.L.; Otero, J.E.; Munoz-Guijosa, J.M.; Sanz, J.L.M. Listening to students as a way of improving teaching: Application of qfd-based techniques to a final year subject. Int. J. Eng. Educ. 2010, 26, 1508-1523.

59. Sohn, S.Y.; Kim, A. Quality Function Deployment for Engineering Curriculum Redesign; Engineers Australia: Barton, Australia, 2009.

60. Nirachara, B.; Sakesun, S.; Napisporn, M.; Supapan, C. Application of quality function deployment for designing and developing a curriculum for industrial engineering at prince of songkla university. Songklanakarin J. Sci. Technol. 2008, 30, 349-353.

61. Raharjo, H.; Min, X.; Goh, T.N.; Brombacher, A.C. A methodology to improve higher education quality using the quality function deployment and analytic hierarchy process. Total Qual. Manag. Bus. Excell. 2007, 18, 1097-1115. [CrossRef]

62. Ictenbas, B.D.; Eryilmaz, H. Linking employers' expectations with teaching methods: Quality function deployment approach. Procedia Soc. Behav. Sci. 2011, 28, 568-572. [CrossRef]

63. Hallowell, M.; Tatum, C.; Rowings, J. Findings and path forward: Leveraging project and career success. Pract. Period. Struct. Des. Constr. 2014, 19, 142-147. [CrossRef]

64. Hou, A.; Ince, M.; Tsai, S.; Chiang, C. Quality assurance of quality assurance agencies from an asian perspective: Regulation, autonomy and accountability. Asia Pac. Educ. Rev. 2015, 16, 95-106. [CrossRef]

65. Rohan, R.; Ionescu, N. Quality management approach in qualifications framework implementation in industrial engineering. Appl. Mech. Mater. 2015, 760, 721-726. [CrossRef]

66. Mehta, N.; Verma, P.; Seth, N. Total quality management implementation in engineering education in india: An interpretive structural modelling approach. Total Qual. Manag. Bus. Excell. 2014, 25, 124-140. [CrossRef]

67. Brackin, P. Assessing engineering education: An industrial analogy. Int. J. Engng Ed. 2002, 18, 151-156.

68. Suliman, S.M.A. Application of qfd in engineering education curriculum development and review. Int. J. Contin. Eng. Educ. Lifelong Learn. 2006, 16, 482-492. [CrossRef]

69. Rouyendegh, B.D. Ahp and intuitionistic fuzzy topsis methodology for scm selection. In Advanced Business Analytics; Garc García Márquez, F.P., Lev, B., Eds.; Springer: Cham, Switzerland, 2015; pp. 181-194.

70. Kou, G.; Ergu, D.; Peng, Y.; Shi, Y. IBMM for inconsistent data identification and adjustment in the ahp/anp. In Data Processing for the AHP/ANP; Kou, G., Ergu, D., Peng, Y., Shi, Y., Eds.; Springer: Heidelberg, Germany, 2013; pp. 29-64.

71. Benedetto, F.; Giunta, G.; Mastroeni, L. A maximum entropy method to assess the predictability of financial and commodity prices. Digit. Signal Process. 2015, 46, 19-31. [CrossRef]

72. Mei-rong, S.; Zhi-feng, Y. Set pair analysis for urban ecosystem health assessment based on emergy-vitality index. China Environ. Sci. 2009, 29, 892-896. 
73. Lehmann, E.L.; D'Abrera, H.J.M. Nonparametrics: Statistical Methods Based on Ranks, rev. ed.; Prentice-Hall: Englewood Cliffs, NJ, USA, 1998.

74. Creswell, J.W. Educational Research: Planning, Conducting, and Evaluating Quantitative and Qualitative Research, 5th ed.; Pearson Education: New York, NY, USA, 2014.

75. Jamalnia, A.; Mahdiraji, H.A.; Sadeghi, M.R.; Hajiagha, S.H.R.; Feili, A. An integrated fuzzy qfd and fuzzy goal programming approach for global facility location-allocation problem. Int. J. Inf. Technol. Decis. Mak. 2014, 13, 263-290. [CrossRef]

76. Upadhyay, R.K.; Gaur, S.K.; Agrawal, V.P. Model Development Using Fuzzy Quality Function Deployment (FQFD) to Assess Student Requirement in Engineering Institutions: An Indian Prospective. Int. J. Engng. Sci. Innov. Tech. 2013, 2, 310-317.

(C) 2016 by the authors; licensee MDPI, Basel, Switzerland. This article is an open access article distributed under the terms and conditions of the Creative Commons Attribution (CC-BY) license (http://creativecommons.org/licenses/by/4.0/). 